\title{
Lefebvre'nin Mekân Kuramının Yapısal ve Kavramsal Çerçevesine Dair Bir Okuma*
}

\author{
Husik GHULYAN**
}

Öz: Makalenin amacı Lefebvre'nin 'Mekânın Üretimi' kitabının bir okumasını gerçekleştirerek, kitapta öne sürülen mekân kuramının yapısının ve temel kavramsal çerçevesinin yeniden değerlendirilmesidir. Bundan hareketle kuramın temel yapisl olarak her üretim tarzında üretilmekte olan mekânların çözümlemesine yönelik Lefebvre'nin önerdiği dönemselleştirmesi dĕgerlendirilmiştir. Ayrıca makalede toplumsal mekânın anlamlandırılması ve kavramsallaştırllması için kuramda öne sürülen mekânsal üçlü değerlendirilmiştir. Böylece, somut bağlamda gerçekleştirilebilecek herhangi bir araştırma için Lefebvre'nin kuramının kolayca uygulanabilir ve benimsenebilir bir kavramsal çerçevesi çizilmiştir.

Anahtar Kelimeler: Henri Lefebvre, mekânın üretimi, mekân dönemselleştirmesi, mekânsal üçlü.

\section{A Reading of the Structural and Conceptual Framework of Lefebvre's Theory of Space}

Abstract: By reading Lefebvre's book 'The Production of Space' book, this paper aims to reassess the structure and main conceptual framework of the theory of space presented in the book. Based on this as a main structure of the theory, Lefebvre's periodization of space - aimed at the tracing the spaces being produced during each mode of production - is discussed. In the paper, the spatial triad aiming at understanding and conceptualization of social space is discussed as well. Thus, for any study of space in different contexts, an easily adoptable and applicable structural and conceptual framework of Lefebvre's theory is presented.

Keywords: Henri Lefebvre, production of space, periodization of space, spatial triad.

\footnotetext{
*Bu makale, yazarın "Mekânın Üretimi Kuramı ve Türkiye'de Kentsel Mekânın Üretimi: Ankara Örneği" adlı doktora tezinden türetilmiştir.

** Doktora Öğrencisi, Ankara Üniversitesi, Sosyal Bilimler Enstitüsü, Siyaset Bilimi ve Kamu Yönetimi Anabilim Dalı 06590 Cebeci/Ankara/Türkiye.
}

Makale gönderim tarihi: 01.02.2017

Makale kabul tarihi: 19.04.2017

Çă̆daş Yerel Yönetimler Dergisi, Cilt 26 Sayı 3, Temmuz 2017, s. 1-29. 


\section{Giriş}

1960-70 sonrası eleştirel sosyal teoride paradigmatik değişimlerin yaşandığı bir dönemi teşkil etmekteydi. Genelde 'mekânsal dönüş' olarak tanımlanan bu dönem mekâna dönük ve mekânı ele alan önemli kuramsal çalışmaların ve tartışmaların ortaya çıkışına tanık olmuştur. Söz konusu çalışma ve tartışmalar genel olarak Marksist gelenekten gelen D. Harvey, M. Castells ve H. Lefebvre'nin kuramsallaşmalarına dayanmaktaydı. 1960-70'li yıllarda bu çalışmaların özellikle Marksizm bünyesinde ortaya çıkması tesadüf değildi, zira kapitalist üretim ile toplumsal ilişkilerin hüküm sürdüğü düzen aynı dönemde büyük bir bunalım ve ondan çıkış yolunun arayışları içerisindeydi. Dolayısıyla mevcut durum, mekân sorunsalının ve kapitalist gelişme ile mekân arasındaki ilişkilerin yeniden değerlendirilmesi ihtiyacını doğurmuştu.

Bahsi geçen dönemde özellikle kent ile mekân sorunsalı konusunda Lefebvre'nin etkisi çok büyüktür. Onun 'Kentsel Devrim' (2003) çalışması özellikle bu dönemde dünya çapında meydana gelen değişiklikler bağlamında önem taşımaktadır. 'Kapitalizmin Hayatta Kalışı' (1976b) çalışması ise üretim ilişkilerinin yeniden üretim ile mekân arasındaki diyalektik ilişkisi açısından kayda değerdir. 1970 öncesi külliyatında genel Marksist tartışmalara (Lefebvre, 2009 vd.), gündelik hayat (Lefebvre, 1976a, 1991, 2002) ve kent ile kentleşme (Lefebvre, 1996, 2003 vd.) tartışmalarına katkılarını sunan Lefebvre, 1974'te yayınladığı 'Mekânın Üretimi' (2014) eseriyle bir taraftan Marksist teoriye mekân boyutu katarken, diğer taraftan mekân tartışmalarına önemli Marksist açılımlar sağlamıştır. Bu çalışmasının en önemli tarafı ise gerek kendisinin bir önceki çalışmalarına ve genel olarak Marksist kuram bünyesinde sistematik olmayan mekân analizlerine gerekse sosyal teorideki diğer mekân analizlerine k1yasla daha kapsamlı ve çok taraflı bir mekân teorisi ortaya koymayı amaçlamasidir.

O zamandan beri ortaya çıkan kent, kentsel mekân ve genel olarak mekân ile ilgili tartışma ve çalışmalara bakıldığında Lefebvre'nin mekân ve mekânın üretimi kuramının hem kuramsal tartışmalar hem de somut araştırmalar için önemli bir zemin oluşturduğu görülmektedir. Örneğin, Soja'nın kuramsal incelemeleri (Soja, 1989, 2000), onun Lefebvre'nin mekân analizine dayalı ve postmodern mekânları ele alan çalışmaları (Soja, 1996, 2014) belirtilmelidir. Brenner ve diğerlerinin mekânsal ölçek meselesi (Brenner, 1997a, 2001; Brenner ve Elden, 2009; Brenner ve Schmid, 2015), ileri kapitalizmde mekânın üretimi olarak mekânsal yeniden ölçeklenme süreçleri ile yeni devlet mekânları üzerine çalışmalar1 (Brenner, 1997b, 1999, 2000, 2002, 2003, 2004a, 2004b) da Lefebvre'nin mekân kuramına doğrudan veya dolaylı olarak dayandığ 1 da belirtilmelidir. Burada Gottdiener'in, Lefebvre'nin mekânın üretimi kuramına dayanan ve metropolitenleşme süreçlerini bir mekân üretim süreci olarak çözümleyen 
(Gottdiener, 1994), ayrıca ileri kapitalizmde mekânın rolünü ele alan (Gottdiener, 1987) çalışmaları belirtilmelidir. Gottdiener'in mekânın üretimi kuramına diğer önemli katkısı, Lefebvre'nin mekânın tüketimi kavramının, mekânın üretimi süreçlerindeki rolünün daha kapsamlı bir biçimde araştırmasıdır. Gottdiener, son dönemlerde gittikçe daha yaygın olarak görülen mekânın tüketimi süreçlerini ve tematik mekânların üretimini ele alarak mekân semiyolojisi konusunda da önemli katkılar sunmuştur (Gottdiener, 1982, 2001a, 2001b, 2011). Neil Smith ise Lefebvre'nin kuramında dile getirilen önemli bir sorunsa11- kapitalizmde mekânın üretiminin, sistemin hayatta kalışındaki rolü- ele almıştır ve Lefebvre'nin argümanından esinlenerek doğanın üretimi argümanını geliştirmiştir (Smith, 2008). Bu tartışmalar 1970 sonrası 'mekânsal dönüş’te Lefebvre'nin mekân kuramının etkisinin sadece birkaç örneğidir ve bu etki kendi başına daha kapsamlı bir değerlendirmeye konu olabilir.

Türkiye'ye gelince Lefebvre'nin kuramının gerek kuramsal düzlemde yaygın olarak tartışıldığ nimsenip uygulandığı görülmektedir. Türkiye'deki farklı ölçeklerde mekânı ve olayları konu eden çok sayıda çalışmaların ortak noktası olarak Lefebvre'nin önerdiği mekânsal üçlünün ve onun unsurlarının yaygın olarak benimsenip kullanıldığı görülmektedir. Oysa mekânsal üçlü yapısal olarak Lefebvre'nin kuramının sadece bir bileşenini oluşturmaktadır. ${ }^{1}$ Onun kuramının bir diğer kilit unsuru olan mekân dönemselleştirmesine ise tartışmalarda az yer verildiği ve somut bağlamlarda bir çözümleme çerçevesi olarak pek kullanılmadığı görülmektedir. Bundan yola çıkarak makalede Lefebvre'nin kuramının temel yapısını oluşturan bu iki unsuru ele alarak ve her iki unsurun temel kavramsal bileşenlerini tartışarak onun kuramının bütünlüğünün tekrardan değerlendirilmesi ve mekân teorisine Lefebvre'nin özgün katkıları olan mekân dönemselleştirmesi ile mekânsal üçlünün bir arada değerlendirilmesi amaçlanmıştır.

\footnotetext{
${ }^{1}$ Mekânsal üçlü, bugünlerde akademide özellikle gündelik hayat ve ilgili konularda yaygın olarak kullanılan bir araştırma çerçevesi haline gelmiştir. Bu, Lefebvre'nin teorisinin ve özellikle mekânsal üçlüsünün epistemolojik önemini gösteren bir husus olmakla beraber, üçlünün ve onun farklı unsurlarının, Lefebvre'nin teorisi bağlamından çıkarılıp, kapitalist toplumsal ilişkileri hesaba katmadan çeşitli konuların araştırılması için kullanıldığında, üçlü sadece betimleyici bir çerçeve olarak karşımızda çıkmaktadır. Ayırca mekânsal üçlü, Lefebve'nin mekân kuramının en temel unsuru olarak tanımlandığı ve böylece onun kuramının mekânsal üçlüye indirgendiği görülmektedir. Oysa mekânsal üçlü Harvey'in de haklı olarak belirttiği gibi Lefebvre'nin özgün önerisi değildir. Zira Lefebvre, mekânsal üçlünün kurgusunu Cassirer'den (Cassirer, 1944) yararlanarak geliştirip ortaya koymuştur (Harvey, 2006). Dolayısıyla, Lefebvre tarafından mekânsal üçlü önermesi önemli olmakla beraber kendi başına pek özgün bir önerme olmasa da, mekân dönemselleştimesi bağlamında özgün bir çerçeve olarak karşımıza çıkmaktadır. Benzer biçimde mekân dönemselleştirmesi Marksist teoride kabul gören üretim tarzlarına denk düştüğünden dolayı kendine özgü bir önerme değildir. Dolayısıyla, Lefebvre'nin kuramı ancak bu iki unsur bir arada değerlendirildiği zaman özgünlüğe kavuşmaktadır.
} 


\section{Mekânın Üretimi Kuramının Kavramsal Çerçevesi Toplumsal Olarak Üretilen Mekânın Tarihi: Mekân Dönemselleştirmesi}

Lefebvre, "(toplumsal) mekân (toplumsal) bir üründür” varsayımının bir içerimi olarak, önemli bir saptamada bulunur:

Mekân üretimi ve mekânın üretimi süreci varsa, tarih de vardır (...) Üretici güçler (doğa, çalışma ve çalışmanın örgütlenmesi, teknik ve bilgiler) ve elbette üretim ilişkileri, mekân üretiminde-belirlenmesi gereken-bir role sahiptirler. Bir üretim tarzından diğerine geçiş çok büyük önem taş[ır]; çünkü bu, mekânı altüst ederek mekâna dâhil olabilen toplumsal üretim ilişkileri içindeki etkisidir. Her üretim tarzı-hipotez gereği-kendine uygun mekâna sahip olduğundan, bu geçiş sırasında yeni bir mekân üretilir (Lefebvre, 2014: 75).

Bundan yola çıarak Lefebvre mekân konusunda önemli bir dönemselleştirme önermektedir. $\mathrm{Bu}$ dönemselleştirme, Lefebvre'nin belirtiğine göre (Lefebvre, 2014: 76) ve çalışmasının içeriğinden de görüldüğü üzere mekânın belirli bir kodunun oluşumu, yerleşmesi, çöküşü ve parçalanması gibi özel durumları incelemekle sınırlı değildir. Ayrıca, dönemselleştirme genel üretim tarzları ve bu üretim tarzlarının hâkim olduğu toplumların tarihini ve kurumlarını da hesaba katma yönündedir.

$\mathrm{Bu}$ dönemselleştirmede beş mekândan söz edilmektedir; mutlak mekân, kutsal mekân, tarihsel mekân, soyut mekân, çelişkili mekân ve diferansiyel mekân. ${ }^{2}$ Böyle bir dönemselleştirmenin, özellikle Marksist teoride yaygın olan üretim tarzlarının dönemselleştirilmesiyle örtüştügünü rahatça söyleyebiliriz. Fakat nas1l her müteakip üretim tarzında bir öncekinin tamamen kaybolmadığ gibi, hatta bazı durumlarda birbiriyle iç içe geçmiş üretim tarzlarının ve toplumsal ilişkilerin söz konusu olduğu gibi mekân konusunda da böyle bir durumla karşı karşıyayız. Shields tarafindan bu dönemselleştirme, haklı olarak "çizgisel ve tarihsel gelişimin Avrosentrik modellemesi" olarak nitelendirilmesine rağmen (Shields, 2005: 170), Lefebvre'nin mekân ve mekânın üretimi konusunda böyle bir dönemselleştirme önermesi şu ana dek eleştirel sosyal teoride en temel ve tutarlı olandır. Dolayısıyla, bu önermelerin epistemolojik sınırları ve geçerliliği ancak somut zaman-mekân bağlamında tartışıldığında daha netleşebilir. Dolayısıyla, Lefebvre'nin bu “Avrosentrik" yaklaşımı, onun farklı dönem mekânları ile ilgili farklı saptamaları ve genel olarak bu dönemselleştirmesi belirli zamanmekân bağlamlarında aynı biçimde kullanılamayacağı göz önünde bulundurulmalıdır.

\footnotetext{
${ }^{2} \mathrm{Bu}$ dönemselleştirme ile ilgili daha detaylı tartışmalar ve değerlendirmeler için bkz. (Boer, 2015 özellikle 5. Bölüm; Grönlund, 1993; Shields, 2005).
} 
Boer (2015), Marksist teorideki üretim tarzları ve Lefebvre'nin dönemselleştirmesini değerlendirerek (bu arada Shields'in bahsi geçen eserinden de yararlanarak) şöyle bir şema önerir (bkz. Tablo 1).

Tablo 1. Marksist Teorideki Üretim Tarzları ve Lefebvre'nin Mekân Dönemselleştirmesi

\begin{tabular}{ll}
\hline Üretim Tarzı & \multicolumn{1}{c}{ Mekân } \\
\hline $\begin{array}{l}\text { Avcllı ve toplama, tarım ve hayvancılık (kabi- mutlak mekân (doğa) } \\
\text { le toplumu, ilkel komünizm) }\end{array}$ \\
\hline $\begin{array}{l}\text { Neolitik tarım (gens veya hiyerarşik akraba } \\
\text { toplumları) }\end{array}$ \\
\hline
\end{tabular}

Asya tipi üretim tarzl ('oryantal despotizm've kutsal mekân tanrisal krallar)

\begin{tabular}{ll}
\hline $\begin{array}{l}\text { Antik veya klasik üretim tarzı (polis veya oli- } \\
\text { garşik kölelik toplumu) }\end{array}$ & $\begin{array}{l}\text { tarihsel mekân (siyasi devletler, Yunan şe- } \\
\text { hir devletleri, Roma imparatorluğu) }\end{array}$ \\
\hline Feodalizm & kutsal mekân \\
\hline
\end{tabular}

Erken kapitalizm (klasik ve monopol biçimler) soyut mekân (politik-ekonomik mekân)

\begin{tabular}{ll}
\hline Geç kapitalizm & $\begin{array}{l}\text { çelişkili mekân (küresel sermayeye karşı } \\
\text { yerel anlam) }\end{array}$ \\
\hline Komünizm & $\begin{array}{l}\text { diferansiyel mekân (farklılı̆̆a ve yaşanan } \\
\text { deneyime yeniden değer biçen gelecek) }\end{array}$
\end{tabular}

Kaynak: (Boer, 2015: 123).

Yukarıdaki şemayı göz önünde bulundurarak ve Lefebvre'den yararlanarak, mekân dönemselleştirmesini daha detaylı olarak ele alalım.

\section{Mutlak Mekân}

Lefebvre, (toplumsal) tarihin başlangıcını doğanın mutlak mekânına dayandırmaktadır. Bu mekânın "kökeni tarımcı-pastoral bir mekân parçasıdır, yani köylülerin, göçebe ya da yarı göçebe çobanların adlandırdığı ve çalıştığı yerler kümesidir" (Lefebvre, 2014: 245-46). İnsan eli değmemiş birinci doğa üzerine köylülerin, göçebelerin ya da yarı göçebe çobanların ilkel pratikleri sonucunda toplumsal mekân yükselir ve onun sınırları ve kapsamı belirlenir. Mutlak mekânın temel özelliği insan yaşamının doğayla, doğanın ritimleri ve güçleriyle, dolayısıyla henüz doğallıktan kopmamış mekânla yakın bir ilişki ve uyum içinde olmasıdır. O yüzden mutlak mekânın üretildiği toplumlarda insan faaliyeti ne kadar bu mekânı dönüştürmeye çalışsa da, ona farklı bir nitelik ve karakter atfetse de, yine "bu mekân tasarlanan değil, 'yaşanan' mekândır, mekân temsi- 
linden ziyade temsil mekânıdır" (Lefebvre, 2014: 247)³. Başka bir ifade ile ilkel topluluklar kendi mekânlarıyla ve doğa ile iç içe geçmiş olarak yaşadıkları ve bir şekilde doğayla uyum içinde üretim ve yeniden üretim faaliyetlerini sürdürdüklerinden dolayı insanın mekâna tahakküm boyutları ve kapasitesi mekânı tamamıyla doğal bağlamdan koparıp, tasarlanan mekâna dönüştürme seviyesinde değildi. Ayrıca teknolojik gelişmişlik boyutu nedeniyle, mekân deneyimlemesi ve mekânsal pratik de farklıydı. Genelde ilkel araçlarla avcılık, toplay1c1lık veya tarımla uğraşan bu toplumlarda doğaya ve doğal mekâna bağlılığ ve bağımlılığı her açıdan daha güçlü olduğu için, mekân deneyimlemesi tamamıyla doğrudandı ve her şey doğal olan mekânın özelliklerine göre algılanıp değerlendirilmekteydi. Günlük hayatın ritimleri de doğanın ritimleriyle uyum içerisindeydi. Doğayla böyle sıkı ilişki söz konusu olunca bu topluluklarda yaşlanma, cinsellik, doğurganlık gibi faaliyetler ile ilgili ritüeller ve seremoniler hep doğaya ve doğal mekâna hitap eder. O yüzden bu topluluklarda birbirinden ayrılması zor olan tasarlanan mekân (mekân temsilleri) ile yaşanan mekân (temsil mekânlar) insan bedenine ve özellikle doğa ve doğurganlıkla tekabül eden kadın bedenine benzetme yoluyla biçimlendirilmekteydi (Mumford, 2013: 24-25). Temsil mekânları da insana ve bedene örtük bir şekilde hitap etmekteydi, M1sır'daki 'anne' simgesi anlamına gelen 'ev' veya 'kasaba' hiyeroglifleri böyle temsil mekânlarının örneğidir (Mumford, 2013: 25).

Mutlak mekân insanların sadece günlük yaşamını sürdürdüğü süreçte üretildiği ve yeniden üretildiği anlamına gelmez, "mutlak mekân, aynı zamanda ve özellikle ölümün de mekânıdır” (Lefebvre, 2014: 247). Mekânın üretimi açısından özellikle ölümün mekânının, mezarlıkların önemi vurgulanmalıdır. Mumford'a göre, Paleolitik çağın göçebelik döneminde ilk kalıcı yerleşim alanına ölüler sahipti zira toplayıcılık ve avcılık, insanları belli bir alanı sürekli bir yerleşim yeri olarak kullanmaya teşvik etmediği için en azından ölüler bu ayrıcalığa sahipti. Dolayısıyla "canlıların kentinden önce ölülerin kenti vardı. Bir anlamda, ölülerin kenti her canlılar kentinin öncülü, neredeyse onun özüdür" (Mumford, 2013: 18). Lefebvre'ye göre ise "mezarların mekânı eğer bir tanrı ya da kral mezarı değilse, doğumun, ölümün ve unutmanın mekânına benzemekle yetinir". Bir tanrı ya da kral mezarı durumunda ise "sivil birliğin, dolayısıylabölge insanları da dâhil olmak üzere-site mensupları arasındaki bağın bekçisi olan mutlak mekân, bütün dağınık güçleri toplayarak kendi içinde barındıran" ve böylece "canlılar üzerindeki mutlak iktidarının mekânıdır" (Lefebvre, 2014: 247). Bunun örneği, Mısır veya Meksika'daki piramitler, Mezopotamya'daki ziguratlardır. Mumford, dağ mağarası erken insanın ilk mimari mekân anlayışını oluşturduğu varsayarak, piramit, zigurat ve benzer yapıların "tümüyle insan

\footnotetext{
${ }^{3}$ Mekân temsil, temsil mekânı ve mekânsal pratikler kavramları bu makalenin bir sonraki bölümünde ele alınacaktır.
} 
elinden çıkma bir dağ olan ve bilinçli olarak dağa benzetilerek inşa edilmiş" (Mumford, 2013: 20) ve mağarayı model olarak alan yapılar olarak belirtir. Yani, Lefebvre'nin kavramıla, bu mutlak mekânlar organik toplulukların doğayı andiran mekân temsilleridir.

Fakat mutlak mekân, yavaş yavaş siyasi ve dini iktidar tarafindan işgal olunmaya başlandı. Doğanın parçaları kutsanarak büyüsel ve dini iktidar tarafından işgal edilerek, bu mekân siyasi denetim aracı haline getirildi. Böylece, mutlak mekânın (daha doğrusu onun bir kısmının) gittikçe kutsal mekâna evrilmesine tanık olmaktayız. Fakat "kan, toprak, dil topluluklarının ürettiği mutlak mekân" tamamıla kaybolmadı, müteakip toplumsal mekânların "tabakası ya da tortusu olarak, temsil mekânlarının dayanağı olarak" (Lefebvre, 2014: 77) birinci doğanın kalıntılarında varlığını sürdürmüştür ve müteakip toplumlarda dinsel, büyüsel, politik sembolizmlerle temsil mekânlarının dayanağını oluşturmuştur.

Aslında Lefebvre'nin çalışmasında mutlak mekânın çok geniş anlamda kullanıldığı görülebilir, şöyle ki bu kavram kutsal mekân anlamına da gelir ya da onlar arasında ayrım yapılmamaktadır. O yüzden bazen bir mekândan diğerine 'geçişi' Lefebvre'de anlaşılır değildir. Ayrıca bu anlaşmazlık, onun çalışmasında kutsal veya tarihsel mekân için ayrı bir bölüm ayrılmadığından, "mutlak mekândan soyut mekâna" geçiş gibi bir başlığın varlığından ve kutsal mekân kavramını neredeyse hiç kullanmadığından kaynaklanmaktadır. Fakat bunlara rağmen kutsal mekân onun mekân analizinde ve dönemselleştirmesinde önemli yere sahiptir. Dolayısıyla Lefebvre'nin mutlak mekân kavramı kutsal mekân kavramıla karıştırılmamalıdır.

\section{Kutsal Mekân}

Kutsal mekânın ortaya çıkışı ilk şehir devletlerinin kurulmasına, Asya tipi üretim tarzına ve feodalizme denk geldiği söylenebilir. Bu mekânın paradoksal özelliklerinden biri, bir taraftan uygulanan siyasi iktidarın eylemiyle, onun doğal bağlamdan çıkarılmış olması, diğer taraftan onun yine de doğa olarak alg1lanmaya devam etmesidir. Dinsel olduğu kadar siyasal da olan kutsal mekân "kendisini özdeşleşme-taklit etme şeklindeki iki büyük prosedüre tabi kılan dinsel kurumlar içerir. İmgelemin ve düşünümselliğin de kategorileri olacak bu zihinsel kategoriler mekânsal formlar şeklinde ortaya çıkar" (Lefebvre, 2014: 245-246, 248). Kutsal mekânın hâkim olduğu toplumlarda merkezi iktidar bu formları içeren belirli sitelere toplanmıştır ve artık toplumsal mekânda merkez ile periferi arasında, şehir ile kasaba arasında ayrım ortaya çıkmıştır. Bu formların ortaya çıkmasıyla beraber, gittikçe kutsal mekânın maddi genişlemesi söz

\footnotetext{
4 "Evrenin özetleri olan bu formlar ya karedir (mandala), ya çember ve küredir, ya üçgendir, ya da tanrısal ilkenin işgal ettiği rasyonel bir hacimdir, ya da haç şeklindedir...” (Lefebvre, 2014: 248).
} 
konusudur. Bu genişleme "ruhban kastının ve elinde tuttuğu ya da kullandığı siyasal gücün yararına, bu prosedürler (özdeşleşme-taklit etme) sayesinde meydana gelir" (Lefebvre, 2014: 248). Ayrıca, önceden var olan mekân bu genişleyen ve daha da merkezileşen kutsal düzenin ve merkezin tahakkümüne maruz kalmıştır.

Eskiden "şehir, kentsel mekân, kimi zaman güçlükle de olsa, kontrol ettiği kırsal mekânla simbiyoz halinde yaşar[dı]", fakat Şehir-Devletin ortaya çıkışıyla beraber, sabit bir merkez oluşur, şehir-devlet "kendini merkez ve ayrıcalıklı yer haline getirir ve etrafını da damgasını taşıyan bir periferiyle çevirir. Önceden var olan geniş mekân artık tanrısal bir düzene tabidir" (Lefebvre, 2014: 246). Bu, aynı zamanda toplumsal ve doğal dünyalar arasında mekânsal ayrımın başlangıcı, toplumsal mekânda merkez ile periferi arasındaki ayrımın başlangıclydi.

Kutsal mekânın gittikçe özdeşleşme-taklit etme gibi imgelem ve düşünümsel prosedürler aracılığıyla sürekli yeniden üretilmesi, genişlemesi ve daha da siyasi ve dini nitelik kazanması, ona kurmaca bir nitelik kazandırır. Fakat bu mekân yine de mutlaktır, mutlaklığın kaynağı ise doğadan ziyade dini ve siyasi referansıdır, başka bir ifade ile bu mekânın mutlaklığının temel kaynağı "sembolizm aracılığıyla politikaya tahsis edilmesi" (Lefebvre, 2014: 76-77) ve kutsanarak ritüel ile törenler aracılı̆̆ıyla dini nitelik kazandırılmasıdır. O yüzden, "aşağı yukarı her yerde, bütün toplumlarda, mutlak mekân, tehditlerle, cezalandırmalarla, hep hissedilen duygularla, zihne değil bedenlere hitap eden anlamla yüklüdür" (Lefebvre, 2014: 247). Bu mutlaklık niteliği sayesinde ise

söz konusu toplumlardaki her şey bu yerlere göre yerleşir, algılanır, yorumlanır... $\mathrm{Bu}$, ayrılmaz biçimde zihinsel ve toplumsal olan ve söz konusu grupların (önce Şehir-Devlet) bütün varlığını içeren ve böyle anlaşılması gereken bir mekândır (Lefebvre, 2014: 251-52).

Kutsal mekânla beraber değişen diğer önemli unsur önceki "biyomorfik ve antropolojik olan toplumsal mekânın" dolayımsılı̆ğının aşılmasıdır. Şöyle ki, ilkel grupların ürettiği mekân, onların üyelerinin hiyerarşik sınıflandırılmasına denk düşerdi ve "bu sınıflandırmayı her daim güncel ve mevcut kılan bu mekândır". Fakat bu hiyerarşinin içerdiği normlara topluluk üyeleri bilmeden uyarlar ve bu normları daha çok mekânsal olarak ve dolayımsızlık içinde yaşarlar (Lefebvre, 2014: 241-42). Kutsal mekânın üretimiyle beraber tehdit ile cezalandırmalar, ayrıcalıklı ile belirlenmiş yerler, kutsal ile lanetli yerlerden oluşan bu mekânda, toplumsal normların da mekânsal olarak yaşanmasına devam edilir. Fakat artık dolayımsızlık içinde değil, bu süreçte kutsal mekânın içerdiği dini/siyasi kurumların dolayımlığ 1 öne çıkmaktadır. Ayrıca, bu dolayımlığı nedeniyle, önceden simbiyoz, uyum veya "organik bir bağdaşıklık" halinde yaşayan kent ile kır arasında kopuş ve çatışmalı bir ilişki ortaya çıkar. Dinsel ve siyasi 
merkez şehir ile kır, kentsel mekân ile tarımsal mekân arasındaki bu çatışmalı ilişkinin damgasını taşır. Yasaklama ve koruma kuralları ile merkezi mekânlara dinsel ve büyülü nitelik kazandırması, dışarıdan, kırdan gelen gerçek tehditlere cevaptır. Ayrıca böylelikle siyasi ve dini merkez kırsal kesimdeki artı ürüne el koyma da sağlamaktadır. Çünkü idari, siyasi ve askeri yetkileri elinde tutuğu için kırsal alana koruma sağlar (Lefebvre, 2014: 246). ${ }^{5}$

Böylece, ilk şehir-devletlerin ortaya çıkışından yukarı Ortaçağ'a (10001300) dek kutsal mekânın üretim ve yeniden üretimi söz konusudur. Bu dönem için siyasi, ekonomi ve dini düzlemleri birbirinden ayırmanın mümkün olmad1ğını belirterek, yine de böyle bir mekânın, siyasi ile dini iktidarın, ekonomik işlevlerin ve daha çok söz konusu toplumda kozmolojik ve dinsel kodlar (evrenin imgesi) ile ilgili temsillerin toplam ürünü olduğu söylenebilir. Yukarı Ortaçağ'da kutsal mekânın yerine yeni bir mekân yerleşmeye başladı. Bu zamandan itibaren dinsel ve kozmolojik kodlar olmadan mekânın üretimi söz konusu olabildi. Lefebvre'nin tabiriyle "Roma'nın dinsel ve siyasal mekânını laikleştiren yeni bir mekân yerleşmiştir. Bu da onu tarihsel mekâna, birikim mekânına dönüşmeye hazırlamıştır” (Lefebvre, 2014: 264).

\section{Tarihsel Mekân}

Yukarıda değinildiği üzere, tarihsel güçler mutlak mekânın doğallığını durmadan parçalayarak, onun kalıntıları üzerine birikim mekânını tesis ettiler. Bu sürecin temelinde yatan, özel mülkiyetin niteliğinin değişimi ve kamusal ile özel arasında ortaya çıkan ayrımdı. Kutsal veya mutlak mekânın parçalanması Lefebvre'ye göre Roma'yı istila eden 'barbarlar' tarafından gerçekleşti. Bu istila birkaç yönden yeni bir mekânın üretimine imkân sağladı. Roma dünyasını altüst eden önemli değişimlerden biri Cermen barbarları tarafından Avrupa'da ilk büyük tarım reformunun gerçekleştirilmesiydi (Lefebvre, 2014: 243). Bu değişim, sistematik tarıma geçişi, böylece feodalizm olarak tanımlanan üretim tarzına ve ona özgü üretim ilişkilerine geçişi sağladı. Bu değişim, Barbarların yerleşmesiyle özel mülkiyetin niteliğinin değişimi ile ortaya çıktı. Barbarlar, Roma İmparatorluğu'ndan kalan "kutsal mülkiyete tecavüz ederek onu döllediler... mekânı temizlediler; en eski işaret noktalarını, tarımc1-pastoral döneminkileri, daha doğrusu tarımcı olmaktan ziyade pastoral dönemindekileri yeniden ortaya çıkardılar" (Lefebvre, 2014: 263-64). Böylece, kutsal özel mülkiyeti laikleştiren yeni mülkiyet ilkesi "doğanın, kozmosun ya da dünyanın seyrine son vererek,

\footnotetext{
${ }^{5}$ Mumford'a göre, dağınık kırsal ekonomi ve örgütlenmeden hayli merkezileşmiş kentsel ekonomiye ve örgütlenmeye geçişini tetikleyen en önemli etken Kral veya Kraliyet kurumuydu. Bu değişimi etkileyen diğer temel unsur dindi. Dolayısıyla, kırsal topluluğa kıyasla, kent, ayrıcalıklı sınıf tarafindan yönetilen topluluktur (Mumford, 2013: 44-55).
} 
yorumlamak yerine dönüştüren mütehakkim eylemlerin yolunu gösteriyordu" (Lefebvre, 2014: 263). ${ }^{6}$

Böylece, barbar istilası Roma özel mülkiyetinin yarı kutsal ve mutlak niteliğini laikleştirerek, eski sosyo-mekânsal düzenin mutlaklığını parçalayarak tarihsel ve soyut mekânların yeni biçimlerinin ortaya çıkmasına imkân tanıdı. Bu parçalanan mekân üzerine, gelişen ticari ilişkilere koşut olarak "bütün zenginlik ve servetlerin: bilgiler, teknikler, para, değerli nesneler, sanat eserleri ve semboller"in mekânı, kısaca birikim mekânı oluşmaya başladı. Bu evrede "hâkim olduğu topraklarla birlikte Batı'nın tarihsel şehri” (Lefebvre, 2014: 77) egemen bir özne durumdadır. Şehirlerin pazar halinde örgütlenmesi ve ticaretin gelişmesiyle değişim değeri yaygınlık kazanır. Küçük çaplı üreticilerin bir araya gelip loncalar, dernekler halinde örgütlenmesi sayesinde ise şehirde ayrıca "toplumsal olarak üretebilen kolektif emekçi sahneye çıkar" (Lefebvre, 2014: 266) ve böylece değişim değerinin yaygınlık kazanması ve soyutlanmasına koşut olarak emeğin soyutlanması da söz konusu olur.?

Üretim faaliyetinin merkezileşmesi ve kolektif emekçinin sahneye çıkışıyla beraber emek süreçleri (üretici faaliyet) toplumsal hayatı sürdüren yeniden üretimden ayrılmaya başladı (Lefebvre, 2014: 77). Eskiden ailevi alanla sınırlı olan ve bütünleşik olan bu süreçlerin ayrımıyla tarihsel mekânda kamusal ile özel alanlar arasındaki ayrım oluşmaya, dolayısıyla mekânsal pratikler de bu ayrıma göre biçimlenmeye başladı.

Bu birikim mekânın ortaya çıkışında, Marksist literatürde yaygın olan tartışmalardan ayrı olarak Lefebvre ilginç bir perspektif sunar. Örneğin, Maurice Dobb, Batı Avrupa' daki feodal sistemin içkin özellikleri olarak serflerin çıkarlarının ihmali, asalak sınıfın genişlemesi, savaş ile eşkıyalık ve soylu ailelerin artan savurganlığını görür. Ayrıca, ona göre bu özellikler Batı Avrupa feodalizminde emek gücünün aşırı sömürülmesine, dolayısıyla feodalizmin çözülüşüne ve kapitalizme geçiş için zemin hazırlayan birikim süreçlerine yol açmıştır (Dobb, 1946). Fakat Lefebvre'ye göre böyle bir teorik analiz' 'neden bu birikim

\footnotetext{
${ }^{6}$ Pirenne, Cermen istilaları sırasında Kilise örgütlenmesinin ve bunun mekânsal kurumsallaşmasının hiç değişmediğini, daha fazlası müteakip imparatorluklarda kendi mekânsal örgütlenmesini koruduğunu ve Roma kentlerinin özeliklerinin korunmasında büyük ölçüde katkıda bulunduğunu belirtir. Ayrıca, ona göre 16. yüzyıldan beri civitas sözcüğ̈̈ 'piskopos kenti' (yani piskopos bölgesinin merkezi) özel anlamını kazandı (Pirenne, 1946: 13-14). Böylece, mekânın üretimi konusunda dinin etkisi farklı boyut kazandı. O yüzden Lefebvre tarafından 'laikleştirme' kavramının kullanılması tesadüf değildir. Bununla Lefebvre, mekânın temsilinde dinsel nitelik taşıyan eski imago mundinin yerine dinden ayrılmış yeni bir imago mundinin yerleşmesini kasteder.

${ }^{7}$ Birbirinden ayrılmaz olan bu gelişmeler, daha sonra hâkim olan feodal üretim tarzının çöküşünü tetikleyen süreçlerdir. Bu sürecin daha detaylı aktarımı için bkz. (Pirenne, 1946). Konu ile dolaylı ilgili olup fakat önemli olan diğer kaynaklardan Feodalizm'den Kapitalizme Geçiş tartışmalarına (Geçiş Tartışması olarak da bilinen) da başvurulabilir, bkz. (Dobb vd., 1985).

${ }^{8}$ Lefebvre, çalışmasında Dobb'a doğrudan atfetmese de, eleştirileri tamamıyla Dobb'un argümanlarına yöneliktir. Bkz. (Lefebvre 2014: 273).
} 
sürecinin bazı koşullarına sahip olan Antikçağda başlamadı' sorusuna tatmin edici hiçbir cevap vermemektedir. Lefebvre'ye göre,

12. yüzyılda Batı Avrupa'da doğan ve yavaş yavaş genişleyen (Fransa, İngiltere, Hollanda, Almanya ve İtalyan) mekân, birikimin mekânıdır, onun beşiği, doğum yeridir. Neden ve nasıll? Çünkü bu laikleşmiş mekân, "dünya"yı ve yeraltı güçlerini tabi kılan Logos ile Kozmos'un dirilişinden kaynaklanır. Logos ve mantıkla birlikte, hukuk yeniden oluşur; sözleşmeye dayalı (şart koşulan) ilişkiler âdetlerin ve geleneksel zulümlerin yerini alır (Lefebvre, 2014: 273).

Böylece, görüldüğü üzere, Lefebvre birikim mekânın oluşmasında hukukun ve mantığın önemine vurgu yapar. Burada önemli olan husus önceki dönemde, Roma döneminde "Logos'un değil, Yasa'nın işareti altında neredeyse aynı adımlarla ilerleyen örgütlenme, düşünce ve mekânın üretiminin" (Lefebvre, 2014: 257) hem bilginin ayrılmaz parçası olan Logos'un hem de praksisin parçası olan Yasa'nın işareti altında ilerlemesidir.

Avrupa'da birikim süreçlerine koşut olarak laikleşen mekânda başka bir süreç de baş gösterir. Lefebvre tarafından mekânın de-kripte edilmesi, yani kriptten ve kriptik mekândan kurtulması olarak tanımlanmaktadır. Eskiden Hıristiyanlık, ölümü kodlayarak, ritüelleştirerek ve seremonileştirerek azizlerin işaret ve temsillerini yeraltı kriptlerde ve mezarlarda, ruhban kastı hariç hiç kimse tarafindan görülmeyen mekânlarda bulundurmaktaydı, bu mekânların yeryüzündeki devamı ise kiliseydi (Lefebvre, 2014: 265-67). Oysa Ortaçağın tarihsel mekânında, 12. yüzyıldan önceki yeraltı mekânı tersine çevirildi. Büyük katedraller, "önceki dinsel yapılar karşısında, mekânın tersyüz oluşunu göstermektedirler" (Lefebvre, 2014: 267). Bu başkalaşım sırasında, yeraltı dünyası artık sadece kilise sıfatıyla dünyanın yüzeyine çıkmaz, aynı zamanda "heykel kriptik resim üzerine zafer kazanır. Binaların cephelerinde sütün başlıklarının, heykellerin çoğalması bundan kaynaklanır" (Lefebvre, 2014: 270). Bu aynı zamanda bedenlerin yüceltilmesinin başlangıcıdır. Ön cephe düzenlenişleriyle başlayan bu süreçte mekân beden işaretleriyle dolduruldu. Fakat yine "canlı ve çıplak beden çok kısıtlı bir yer tutar: Havva, Âdem. Çile çekenler ve mahkûm edilmişler dışında, pek az dişi bedeni vardır." (Lefebvre, 2014: 271). Şiddete işaret eden dikeyliğin ve kırık çizgilerin çoğaldığı bu mekânda "dikeylik, kulelerin politik kibri, kulelerin feodalizmi Göz ile Fallus arasındaki ittifakı şimdiden belirtmektedir" (Lefebvre, 2014: 272). Dolayısıyla, çoğalan kırık çizgiler ve dikeylikler aracılığıyla "bir yanda soyutlama, geometri ve mantıkla, diğer yanda güçle bir gizli anlaşma yapılır" (Lefebvre, 2014: 271).

Görsele doğru bu gelişmeyle beraber, köklü diğer bir değişim, kentin, dolayısıyla kentsel mekânın işlevinin değişimidir. Bir önceki, yani kutsal mekânda ticaret ve tüccar sınıfı genelde surlarla çevrilmiş olan kentin dışındaydı. Bunlar kentteki siyasi ve dini kurumsallaşmalara yabancıydı, hatta onlar tarafindan iyi 
karşılanmazd1. ${ }^{9}$ Fakat 14 . yüzyıldan itibaren tüccar kenti siyasi (ve dini) kentin yerini aldı ve ticaret, kentsel işlev haline gelerek kentsel ve mekânsal biçimi önemli ölçüde etkiledi. Bu mekânsal başkalaşma sonucunda kentsel mekânda "bilginin ve iktidarın sembollerini taşıyan șey artık çan kulesi değildir: Gözetleme kulesi mekâna ve hatta zamana egemendir, çünkü üzerine derhal bir saat eklenecektir" (Lefebvre, 2014: 275). Girişi serbest olan pazar meydanının kent merkezi haline gelmesi (eskiden bu merkezlik işlevi girişi serbest olmayan agoraya ve foruma aitti), onun yol ve sokak ağlarıyla her tarafa açılması, merkezde olan ve saatle donatılan gözetleme kulesi ile beraber gündelik hayatın ritimlerini, mekânsal pratikleri dolayısıyla mekân deneyimlemesi ve anlayışını değiştiren önemli bir süreçti. ${ }^{10}$

Mutlak/kutsal mekânın parçalanması ve üzerine müteakip tarihsel mekânın gelişimi sorunsuz bir süreç değildi. Bu birikim mekânının gelişiminde şiddete işaret eden bazı unsurlar mevcuttu. ${ }^{11} 12$. yüzyıldan 19 . yüzyıla dek birikim mekânına 'savaşların mekânı' eşlik etmiş̧ir. Birikim etrafında dönen bu savaşlar, biriktirilen zenginliklerin harcanmasına ve birikimin daha da büyümesine katkıda bulundu, çünkü "savaş üretici güçleri her zaman güçlendirdi ve tekniği yıkım için kullanırken bir yandan da yetkinleștirdi" ve birikim mekânı böyle canland1, zenginleşti. Bu savaş ve şiddet "Batı Avrupa'yı, tarihin, birikimin, yatırımın mekânı, ekonominin zafer kazandığı emperyalizmin temelini” üretti ve kendini "(Roma menşeili) kemerlerde, kapılarda, meydanlarda, zafer yollarında" kutladı (Lefebvre, 2014: 284-85).

Bu gelişmeler sonucunda tarihsel mekânda en önemli ‘özne' haline gelen şehir "kendi imgesini buldu". Fakat bu imge önceki dönemdeki kozmosun merkezi imgesinden farklıdır. Şehir grafik olarak görselleştirilmeye başlandı ve kent planları yaygınlık kazandı. Fakat bunların henüz indirgemeci bir rolü yoktu, planların bu rolü soyut mekânın yükselişiyle beraber önem kazanacaktır. Şehir planları çoğalırken, bunlarda şehir "bir savaş alanı gibi perspektife konulur ve çoğu zaman bir kuşatma görünümü altındadır, çünkü savaş şehirlerin etrafinda döner" (Lefebvre, 2014: 286). Fakat hiçbir zaman bitmeyen bu savaşlar sonucunda ne kadar şehirler yağmalansa, tahrip edilse de "bu çatışmalar aracılığıyla, bunlar sayesinde, bunlara rağmen şehirler 1ş1 1şı1 parladılar" (Lefebvre, 2014: 286). Ancak (feodalizmden kapitalizme geçiş sürecini de tamamlayan) burjuva devrimleriyle yükselen ve tüm coğrafi mekânı kendi egemenliğinin sınırlarıyla

\footnotetext{
${ }^{9}$ Siyasi ile ticari kent arasındaki bu çelişkili ilişkiler için bkz. (Lefebvre, 2003: 1-23). Konu ile ilgili daha detaylı değerlendirmeler için ayrıca Pirenne'nin yukarıda değinilen (Pirenne, 1946) çalışmasına başvurulabilir.

${ }^{10}$ Bu bağlamda, Avrupa'nın çok sayıda kentinin merkezi hala 'pazar' anlamına gelen sözcüklerle tanımlanmas1 tesadüf değildir. Bunun örneği İtalyanca 'piaza', Lehçe 'rynok' veya Almanca 'markt' sözcükleri ve ilgili toplumlarda kentsel mekânın tanımında bu sözcüklere çok sık rastlanmasıdır.

${ }^{11}$ Lefebvre'nin tarihsel mekânı ele alışında şiddet ve savaşa vurgusunu ilk önce Marx'ın ilkel birikim teorisi çerçevesinde ele almak ve zamanı temel eksen olarak kabul eden bu teoriye bir katkı olarak görmek gerekir.
} 
parçalayan, dağınık bölgeleri ve kent sistemleriyle bütünleştiren ulus devletleriyle, kent ve kentsel mekân geçmişin görkemlilik ve parlaklığını yitirdi. Birikim süreçlerinde kentlerin rolü azalmasa, hatta sanayi kentinin ortaya çıkışıyla daha da önemli hale gelse de ulus devlet ve onun soyut mekânı temel özne haline geldi. Lefebvre'nin tabiri terse çevrilirse, "kentleşen mekân ve zaman" (Lefebvre, 2014: 286) yerini devletleşen mekân ve zamana bıraktığı söylenebilir. Başka bir deyişle, eskiden zamana ve mekâna hâkim olan kent, yerini mekâna ve zamana hâkim olan devlete biraktı. Hâkim 'özne' olan ulus devletin soyut mekânında kent ve kentsel mekân eski 'dünya imgesi' (imago mundi) yerine 'devlet imgesi' (imago statum) kazandı. Kent ve kentsel mekân artık biçim, içerik ve işlev açısından belirli bir dünya imgesi benimseyen devletin imgesidir.

\section{Soyut Mekân}

Artık kısmen belirtildiği üzere, Lefebvre, soyut mekânı şiddet ve savaşın bir ürünü olarak görür, bu siyasal olandır, bir devlet tarafından kurulmuştur, dolayısıyla kurumsaldır. Ayrıca bu mekân birikim süreçleri ve sermayeye tabi olan ve büyük ölçüde onlarla şekillendirilen bir mekândır. Fakat Lefebvre'nin analizinde göze çarpan en önemli nokta, soyut mekânın siyasal boyutuna vurgusudur.

Soyut mekânın temel özellikleri onun doğuşu ve temelinde yatan unsurlardan dolayı, homojenlik ve ondan kaynaklanan araçsallıktır. Temelinde ve doğasında şiddet bulunan, şiddet tekelini elinde bulunduran devletin ilk icraatlarından biri 'yerleştiği' mekânda "direnen ve tehdit eden her şeyi, kısaca söylersek farklı1ıkları yerle bir ederek" dolayısıyla homojenleştirerek, bu "homojen mekân, bir marangoz rendesi, bir buldozer ya da bir savaş arabası olarak" (Lefebvre, 2014: 292) kendi hizmeti altına almasıdır. O yüzden "böyle bir mekânın kullanım değeri münhasıran siyasidir” (Lefebvre, 2014: 294).

Soyut mekânın felsefi temeli, devleti mekânın efendisi olarak gören, devlete rasyonellik atfeden Hegelcilikte yatar. Bu mekânın diğer önemli felsefi temeli doğanın ve mekânın mantıksal ve mekânistik analizine vurgu yapan Kartezyen felsefedir. Özellikle Kartezyen anlayış nedeniyle soyut mekân, "beyaz kâğıdın, çizim tahtasının, planların, kesimlerin, yükseltilerin, maketlerin, yansıtmaların" (Lefebvre, 2014: 215) mekânıdır. "Kavranılır olanı siyasetle, bilgiyi iktidarla kaynaştıran" (Lefebvre, 2014: 314) felsefi temellere dayandığ 1 için, ilk önce bir siyasi araç ve aygit olan soyut mekânda "dar ve duyarsız bir rasyonellik" (Lefebvre, 2014: 215) söz konusudur. Bu rasyonellik, otoriter ve kaba bir mekân pratiğine yol açtı. Mutlak devlet gibi kurumsal bir dayanağı olan bu mekân pratiğinin öncüsü Haussmann'dı. Düz çizgiler, hizalanma ve geometrik perspektifle yöneltilen bu düzen, en yüce kurum olan Devlet tarafindan desteklenmekteydi. Sonradan bunun devamcısı "dik açının diktatörlüğünü" (Lefebvre, 2003: 109) ilan eden Bauhaus ve Le Corbusier olacaktır. Bunların hepsinin kodlandırdığı mekân pratiği, "dağılma, ayrılma, ayrımcılık yoluyla (ve bunlar için- 
de) analitik anlayışın etkinliğì"ni (Lefebvre, 2014: 314) sağladı, yüksek modernizmin soyut mekânın homojen fakat aynı zamanda bölünmüş dolayısıyla çelişkili özelliğini pekiştirdi. Le Corbusier ve ona eşlik eden modern mimarlar, projelerinin temelinde doğanın ritimleri ve doğanın şartları olarak tanımladıkları güneş 1şı̆̆ı, açık mekân ve yeşilliği koydular ve projelerini 'özgürlük' namına yürüttüler. Fakat bu girişimlerin sonucu "mekânın parçalanmasıdır, 'mesken makinesi' ve insan-makinenin yaşam alanı olarak tasarlanan mimari kümenin homojenliğidir, birbirinden ayrılmış ve kentsel kümeyi ayıran unsurların- sokak, şehir- eklemlerinden ayrılmasıdır" (Lefebvre, 2014: 309-10). Bu uygulamalarda kargaşa, oyun ve öğrenme yeri olan sokak tek bir işleve, genelde konut ve iş yeri arasında ulaşım sağlamaya tahsis edildi, "sokağın öğretici, sembolik ve oynak işlevleri Le Corbusier'in gözünden kaçmıştı" (Lefebvre, 2003: 18).

Böyle bir rasyonelliğe dayalı praksisin sonucunda Marx'ın yabancılaşma kavramı başlangıçta üretim süreçleri için açıklayıcı kapasiteye sahipken artık gündelik hayatı da kapsamaya başladı. Böyle bir praksis aracılı̆̆ıyla bedenin mekândan kopuşu, onun duyu organlarıyla mekânın çok taraflı deneyimlemesi ortadan kaldırdı. Soyut mekân kendi başına bir soyutluk değildir, onun deneyimlenmesi soyutluk içerir ${ }^{12}$ yani bu mekân "soyut bir öznenin algisıyla tanımlanır", şöyle ki

Trafikte dolaşan kişi (arabayla) gidebilmek için bakar ve sadece işine yarayanı görür; dolayısıyla (maddileşmiş, makineleşmiş, teknikleşmiş) kendi güzergâhından başka bir şey görmez ve bunu da tek bir açıdan -işlevsel yararcılık açısından- görür: hızlılık, okunurluk, kolaylık... Mekân artık indirgemeleri içinde kendini gösterir (Lefebvre, 2014: 318-19).

Önceki dönemlerde temel referans sistemi olan eş yönlü ve homojen Öklidçi mekân böylece daha da indirgenmektedir. Aynı zamanda diğer bir önemli alanda soyutlanma meydana gelir: "yaşam alanı, meskenin yerine geçer; yaşam alanı işlevsel soyutlamayla nitelenir" (Lefebvre, 2014: 319). Le Corbusier tarafından evin 'yaşama makinesi' olarak tanımlanmas $1^{13}$ ve bu tanıma dayanan praksis bunun en bariz örneğidir.

Fakat soyut mekân ne kadar homojen olarak tanımlansa da, aslında homojen değildir, onun amac1, anlamı homojenliktir (Lefebvre, 2014: 294) ve ancak görünümü homojendir. Bu mekân çok birimlidir, çatışmalı ve çoğuldur, karşıtlıkların zorla birleşimidir. Soyut mekân aristokratlar ile burjuvalar arasındaki toplumsal ve siyasal düzlemdeki uzlaşması sonucunda ortaya çıkmasına rağmen çelişkilidir, kapitalist üretim tarzındaki sermaye ile işçi sınıf arasındaki temel çelişkiyi yansıtır, o çelişkiyi etkiler. Hatta birikim süreçlerinin mantığı ve eşitsiz gelişmesi bağlamında değerlendirildiğinde onun asla homojen olamayacağ 1 da

\footnotetext{
12 “Köpek kavramı havlamaz!” (Lefebvre, 2014: 306).

13 "Une maison est une machine à habiter."
} 
söylenebilir. Çünkü sermaye akışları görünüşte homojenleştirici etkiye sahip olsa da sermaye akışının (ve her akışın!) temeli, farklılık ve eşitsizliktir.

$\mathrm{Bu}$ homojenlik tarihsel mekânda ortaya çıkan ve soyut mekânda tam olgunluğa varan üç unsurla daha da güçlenmektedir. Bunlar geometrik, görsel ve fallik özelliklerdir (oluşturuculardır). Geometrik oluşturucu, homojen olan Öklidçi referans sistemine dayanır. Mekânın tüm biçimlerini 'ölçmek' için bu referans sistemine başvurulması doğal ve bütün toplumsal mekânın çok boyutluluğun indirgenmesini ve dolayısıyla homojenleşmesini sağlar. Mekânın homojenleşmesini pekiştiren diğer unsur görsel oluşturucudur. Görsel, diğer duyular karşısinda başatlık elde eder. "Toplumsal pratiğin bütününü ele geçiren" görsel oluşturucu, geometrik olanla beraber her şeyi birbirine benzetir, homojenleştirir, sadece bir duyu organına hitap ederek, mekânın çok taraflı deneyimlenmesini engeller. Dolayısıyla mekânın soyut bir deneyimlenmesini sağlar, sadece görsele dayanan soyut mekânda tek bir duyu organına işlev yüklenmiş soyut özneyi doğurur. Soyut mekânda gücü, eril doğurganlığı, erkek şiddetini, "şiddete muktedir bir iktidarın mevcudiyetini" simgeleyen fallik oluşturucu, bölünmüş, parsellenmiş soyut mekânın bütünlügünü sağlar, yani parçadan bütüne ve bütünden parçaya geçişi sağlar ve "yerlerin ayrımını homojenleştirir, bu homojenliği varsayar ve dayatır" (Lefebvre, 2014: 123, 294). Görselin ortasında dikeyliğini yükselten fallik oluşturucu böylece belirgin okunurluk ve bütüncüllük sağlar.

Bölünmüşlük ve homojenleşme eğilimleri, mekânın hiyerarşik düzenlenişi, soyut mekânın bir diğer önemli özelliğinin temelinde yatar. Burada söz konusu olan sadece merkez ile periferi arasındaki daha çok ekonomik hiyerarşiye dayanan ilişki değildir. Bu hiyerarşik düzenlenişte devletin ve iktidarın rolü belirgin bir biçimde ortaya çıkar. Devlet, toplumsal 'düzen' sağlamak için mekânı bir siyasi araç ve aygıt olarak görür ve sürekli mekânın üretimine müdahale eder. Altyapı sağlayan, kaynakları yöneten, planlama yetkisine sahip olan devlet soyut mekânın hiyerarşik düzenlenişinden sorumludur; yerler ve mekânları, işlev ve özelliklerine göre hiyerarşik bir düzene sokarak sorumlu olduğu toplumsal düzenin temellerini sağlar. Fakat bu hiyerarşik düzenleniş bir bütünlük olarak ele alındığında evrimsel ve rastlantısal bir süreç değildir, merkez tarafından periferilerin örgütlenmesinin stratejik mantığının sonucudur.

Soyut mekânın belirli özellikleri ve onlarda siyasal iktidarın rolü söz konusu olunca, "siyasi iktidarın siyasal iktidar olarak mekân üretici olmadığı" da belirtilmelidir, yani mekânın üretimi kendiliğinden bir amaç değildir, siyasal iktidar "(ona emanet edilmiş olan) toplumsal ilişkilerin yeniden-üretim yeri ve ortamı olarak mekânı yeniden üretir" (Lefebvre, 2014: 326). Bu durum özellikle kapitalist üretim ilişkilerinin gelişmesiyle beraber çok kritik bir rol kazanmıştır. Bir önceki üretim tarzlarında üretim ilişkilerinin sürdürülmesi ve yeniden üretimi söz konusu olunca bu, mekânda gerçekleştirilirdi ve üretim ve toplumsal ilişki- 
lerin devamlılı̆̆g için genel olarak mekân sorun teşkil etmemekteydi. Oysa kapitalist toplumsal ve üretim ilişkileri, tamamıyla mekânın üretimi, topyekûn ve yekpare bir mekân üretimi aracılığıyla gerçekleşir. Önceki üretim tarzlarına k1yasla kapitalizmde mekânın üretimine yapılan vurgu, sadece bu üretim tarzının kendi devrimci potansiyeline dayanarak üretici güçlerin atılım sağlamasından, bu atılımdan yararlanarak boyut ve ölçek açısından geçmişe kıyasla topyekûn bir mekânın üretimine girişimden kaynaklanmamaktadır. Bu girişimin temeli kapitalizmin stratejik mantığında aranmalıdır, şöyle ki

Despotik olarak aydınlanmış burjuvazi ve kapitalizm, soyut mekândan yararlanarak, meta pazarına kısmen hâkim olmuşlardır. Sermaye pazarına hâkimiyet ise daha güçtür... Çok güçlü bir politik tahakkümden, üretici güçlerin atılımından ve pazarlara yetersiz hâkimiyetten, komşuluk adacıklardan bütün gezegene dek, her kademede mekânsal bir kaos doğar. Burjuvazi ve kapitalizm, kendi tahakküm ürün ve araçlar1na-mekâna- hâkim olmakta bundan böyle güçlük çekmiştir. Pratiği... kendi soyut mekânlarına indirgeyememişleridir. Yeni çelişkiler, mekânın çelişkileri ortaya çıkmış ve tezahür etmiştir. Devletin gücüne ve rasyonelliğine rağmen kapitalizmin yarattığı mekânsal kaos, onun zayıf tarafı, gövdesinin dayanıksızlığı[dır] (Lefebvre, 2014: 90).

Dolayısıyla, kapitalizm ve genel olarak büyüme varlığını ancak bütün mekâna yayılarak sürdürebilmiştir, önceden var olan mekânı ele geçirmekle kalmamış, üretici güçlerin bu yayılmasına üretim ilişkilerinin yeniden üretimi de eşlik etmiş ve sonuç olarak kendi mekânını da üretmiştir. Bu üretim tarzı, öncekiler gibi şeylerin üretimiyle ve yerlere yatırım yaparak başladı, fakat bu süreçte toplumsal ilişkilerin yeniden-üretimi problem oluşturur. $\mathrm{O}$ yüzden kapitalizm doğayı yeniden-üretmeye, kapitalizmin siyasi mekânını gezegen çapında üretmeye ve böylece bu mekâna hâkim olmaya ${ }^{14}$, yeni toplumsal ilişkilerin üretimini engellemek için zamanı indirgemeye, yeniden-üretebilir ve tekrarlanabilir olan yasası altında, mekân ve zaman içindeki farklılıkları ortadan kaldırmaya gerek duydu (Lefebvre, 2014: 330-31). Dolayısıyla Lefebvre'nin "mekânın içinde şeylerin üretiminin yerine mekânın üretimine geçiş" saptaması bu bağlamda değerlendirilmelidir. Mekân içinde şeylerin üretimi, ona eşlik eden üretim araçlarına sahip olma, üretimin denetimi ve idaresi gibi sorunlar da halen devam eder, hatta mekânın üretimi bağlamında bu sorunlar daha çelişkili, yoğun ve şiddetli biçim alırlar. Dolayısıyla, hâkim sınıflar tarafindan "siyasal eylemin sonucu olan fakat bu eylemle örtüşmeyen" (Lefebvre, 2014: 319) soyut mekânın ele geçirilmesi, ondan bir aygıt olarak yararlanılması kapitalist toplum-

\footnotetext{
${ }^{14}$ Özellikle İkinci Dünya Savaşından günümüze dek küresel ve yerel ölçekteki uygulamalar, gezegen çapında kapitalizmin siyasi mekânının sürdürülmesine yöneliktir. Uluslararası çalışmalarda çok bilinen 'Domino Teorisi', Marshall Planı, demokrasi namına savaş ve işgal politikaları, hatta son dönemlerde IMF ve Dünya Bankası tarafından özellikle üçüncü dünya ülkelerine farklı araçlarla neo-liberal politikaları dayatması gibi sayısız örnekler bu varsayımı kanıtlayacak yöndedir.
} 
sal ve üretim ilişkilerinin sürdürülmesi ve yeniden üretilmesi bağlamında değerlendirilmelidir.

Böylece, soyut mekân çok derin ve yoğun çelişkilerle doludur, çelişkiler yansımasıdır, ayrıca var olan çelişkileri daha da derinleştiren özellikler barındırmasaydı, kendisi bir çelişki olmasaydı (yukarıda ele alınmasından anlaşıldığı üzere) iktidar tarafindan bu mekâna bu denli önem atfedilmezdi. Bu denli çelişkili olduğu için Lefebvre'nin mekân dönemselleştirmesinde soyut mekânın bir uzantısı olarak çelişkili mekâna rastlanır. Soyut mekân halen hâkim mekân konumunu sürdürmektedir, fakat son dönemlerde (60-70'li yıllardan itibaren) ileri kapitalizm gelişmeleri, genel olarak mekânın üretimi süreçlerine ve mekân çelişkilerine farklı bir nitelik ve nicelik kazandırdı. Dolayısıyla, günümüzün soyut mekânının temel özelliği çelişkili olmasıdır.

\section{Çelişskili Mekân}

Çelişkili mekân, soyut mekânın yukarıda belirtilen tüm özelliklerine sahiptir, fakat kapitalizmin son dönemdeki gelişmeleri sayesinde soyut mekâna özgü çelişkileri daha da derinleşmiştir. Böylece, soyut mekân, niceliksel ve niteliksel açısından yeni bir sıfatla, çelişkili mekân sıfatıyla ve geçmişe kıyasla daha çok keskin ve görünür bir çelişkiler dizisiyle karşımıza çıkmaktadır. Ayrıca, kapitalist toplumsal ilişkiler gündelik hayatın her alanına yayılırken, önceki evrede, yani endüstriyel kapitalizmde hâkim olan emek ile sermaye arasındaki çelişki, başkalaşmış biçimleriyle hala varlığını sürdürürken, gündelik hayatın her alanına yayılan kapitalist toplumsal ilişkiler yeni çelişkilere yol açmıştır. Böylece emek ile sermeye arasındaki çelişki, üretim ilişkilerinin mekânsal olarak yeniden üretiminin daha genel çelişkileri kapsamına girmiştir. Bu yeni ya da derinleşen çelişkilerin bir bölümü ise dolaylı ve dolaysız olarak mekânın üretimiyle bağlantılıdır.

Soyut mekânın birinci çelişkisi niceliksel ve niteliksel arasındaki çelişkidir. Soyut mekânın temelinde Öklidçi referans sistemi yatar, dolayısıyla bu mekân ölçülür. Fakat "sadece geometrik mekân olarak nicelemekle kalmaz, toplumsal mekân olarak da niceliksel manipülasyonlara tabi olur" (Lefebvre, 2014: 353). $\mathrm{Bu}$ niceleme sürecinde niteliksel olan yok olma eğilimi gösterir. Fakat bu sürecin temelindeki en önemli unsur geometrik bir referans sistemi değildir, çünkü bu referans sistemi çok önceden de vardı. Bu çelişkinin temelinde, kullanım ile mübadele değerleri arasındaki çelişki ve bu çelişkinin mekânsal boyut alması yatar. Mekânın geometrik temsili niceleme sürecine sadece hizmet eder, asıl çelişkiyi açıklamaz. Bu geometrik temsili genel olarak doğanın ve özellikle mekânın parçalanmasına, parsellenmesine imkân sağlamıştır, böylece mekân da alınıp satılabilecek ve mübadele süreçlerine dâhil olabilecek bir hammaddeye, metaya dönüştürmüştür. Bu süreç kapitalist gelişmenin ilk evrelerinde başlamasına rağmen günümüzde kapitalist üretim ilişkileri her alana yayıldığı için 
mekânın nicelemesi aşırı boyutlara ulaşmıştır. Özellikle hızlı kentsel yayılma ve küresel çapta kentsel gelişmeler, eskiden doğa olarak tanımlanan mekânları parçalayıp mübadele süreçlerine dâhil eder, bu mekânlar "niceliksel manipülasyona tabi olur", sonuç ise nitelikselin yok olmasıdır (Lefebvre, 2014: 353-57).

Fakat niteliksel olan hiçbir zaman yok olmaz, buna olan ihtiyaç her zaman kendini hissettirir. Nitelikselin kendini var etmesinin temel nedeni nicelikselin belirli sınırlara tabi olması değildir, şöyle ki mekân genel olarak ve coğrafi mekân özel olarak ne kadar da sınırlı olsa, dolayısıyla niceleme süreçleri için belirli sınırlamalar oluştursa kapitalist toplumsal ilişkilerde başka bir sınır ortaya çıkar. Lefebvre, bunu tüketim mekânından mekânı tüketmeye doğru hareket olarak tanımlar (Lefebvre, 2014: 355). Buna göre,

İnsanlar, genellikle, sermaye birikim alanıyla, üretim mekânıyla ve üretilmiş mekânla, dolayısıyla katı bir şekilde nicelendirilmiş mekânla örtüşen tüketim mekânını belli bir momentte terk ederler... başlangıçta toplumsal olup sonra zorunluluk olan moment. Bu durumda "insanlar" niteliksel bir mekân talep ederler. Bu niteliklerin adı, güneş, kar, denizdir. Doğal ya da taklit olmaların pek önemi yoktur (Lefebvre, 2014: 355).

Böylece "niteliksel olan mekânsal olarak yeniden belirir" (Lefebvre, 2014: 355). Fakat bu süreçte, yani tüketim mekânından mekânı tüketmeye doğru harekette ve nitelikselin baskın hale gelmesinde mekânın niteliği ve kullanım değeri saf haliyle kalmaz. Burada yine kâr oranları yüksek sektörlerin gelişmesine imkân oluşur, sanayi ve üretim buraya nüfuz etmeye başlar, "bir doğal yaşam simülasyonu"na (Lefebvre, 2014: 356) hizmet eder. Dolayısıyla, niceliksel ile niteliksel arasındaki çelişkiyi temsil eden bu süreçte "(ikili) bir karşıtlık değil, üç terimli bir hareket" görülür (Lefebvre, 2014: 357):

- Birinci hareket, tüketim mekânından boş vakitlerle ve boş vakit mekânı içinde mekânın tüketimine yönelik hareket, yani gündelik olandan gündelik olmayana yönelik harekettir. $\mathrm{Bu}$, emek harcamasının ertelenmesi ve sorgulanması dolayısıyla, çalışmadan çalışma olmayana yönelik harekettir (bkz. Şekil 1). Bu bağlamda ayrıca toplumsal yeniden üretimi sağlayan üretim mekânı ile mekânın tüketimi arasındaki çelişki belirtilebilir (ikinci hareket), çünkü mekânın tüketimi üretici tüketime ihtiyaç duyar.

- Üçüncü hareket, emek gücünün ve şeylerin yeniden üretimini sağlayan yaygın anlamdaki tüketim, yani tüketim mekânı ile üretim mekânı arasındadır. Bu hareket "mekân içindeki şeylerin ve (yeniden-üretim amaciyla planlanmış) mekânın yeniden üretilebilirliğinin güvencesi altında, devlet iktidarın denetlendiği bir mekân"da gerçekleşir.

Nitelik ile nicelik, kullanım ile mübadele arasındaki bu çelişki (genelde yaşanan mekân ile tasarlanan mekân arasında bir gerilim de yaratan), görünüşte ikincinin kazanımıyla çözülse de kullanım ve yaşanan mekân her zaman yeni- 
den ortaya çıkar. Buna zemin hazırlayan, "kullanım değerini azami kılan şey, özellikle mekânın siyasal kullanımıdır" (Lefebvre, 2014: 359), bu siyasal kullanımın temeli tasarlanan mekân ve onun baskıcı, soyutlayan, yabancılaştıran niteliğidir. Yukarıda doğanın sınırlarından ve onların kapitalist gelişme tarafindan zorlanmasından bahsettik. Bu sınır zorlaması kaçınılmaz olarak (kapitalist toplumsal ilişkilere özgü ve toplumsal olarak üretilen) kıtlığa yol açar.

Şekil 1. Soyut Mekânın Nicelik-Nitelik Çelişkisinin Üç Terimli Hareketi1 ${ }^{15}$

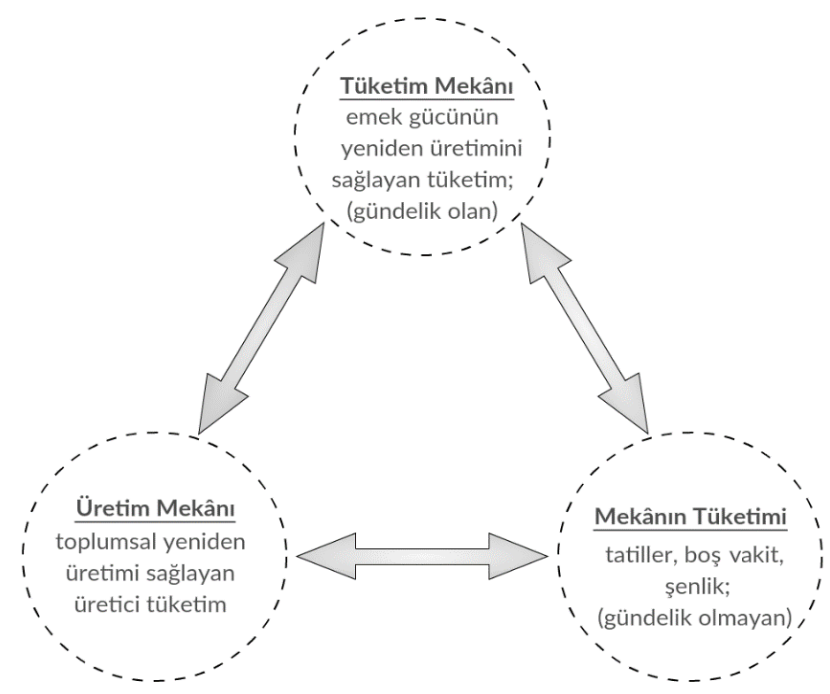

Niteliksel olanın, kullanımın siyasete nüfuz etmesi (Lefebvre'nin saptamas1nı doğrulayacak şekilde) bugün yaygın olarak görülebilir, dahası bugünlerde bu nüfuzun aşırı biçim aldığına da tanık olunabilir. Doğa ve doğal olana vurgu bugünlerde saplantısal (obsesif) bir hal almıştır: ideolojik boyutta çevre, çevrecilik ve çevre korunması adı altında (toplumsal düzenin temellerini hiç de sorgulamayan yönelimle), pratik boyutta ise artık yeni bir kârlı sektör oluşturan çevre ve doğa dostu üretici olup ya da olmayan tüketim adı altında ('çevre dostu iş makineleri', çevre dostu falanca filanca ürünler, doğal yaşam vs.). Sonuç: çevre sorunu olarak tanımlanan, mekânın üretimi genel sürecinden ayrılmazdır, ona eşlik eder ve soyut mekânın nitelik-nicelik, kullanım-mübadele, mülk edinmesahiplenme çelişkilerinin yansımasıdır, o çelişkinin körükleyicisidir. Siyasete nüfuz eden bu çelişkili durum ise, en iyi durumda mekânda şeylerin üretimiyle palyatif çözümlere neden olur, en kötüsünde ise artık belirttiği gibi doğa ve doğal olanın son kalan parçalarını yok eden doğanın ve doğal olanın simülakrasi olan mekânin üretimine neden olur. Çözüm siyasi strateji olmadan, iki seçene-

\footnotetext{
${ }^{15} \mathrm{Bu}$ şema Lefebvre'nin kuramına dayanarak yazar tarafindan hazırlanmıştır.
} 
ğin ortasındadır diyenler de bulunur. Lefebvre'ye göre ise çözüm onun ütopyası olan diferansiyel mekânda yatar.

Bir diğer çelişki bütün ile parça veya genel ile parsel arasındaki olandır. Kapitalizmin kendi varlığını ancak bütün mekâna yayılarak sürdürebilmiştir ve bunu, bu üretim tarzının üretici güçlerinde ileri atılım sağlaması aracılığıyla gerçekleştirmiştir ve sonuçta mekânda şeylerin üretiminden mekânın üretimine geçiş yapmıştır. Bu süreçte soyut mekânda gittikçe daha çelişkili bir ilişki doğar. Bütün mekâna yayılma, mekânda şeylerin üretimi yerine mekânın üretimine geçiş "mekânı global ölçekte (dünya çapında) tahayyül etme ve ele alma kapasitesi" (Lefebvre, 2014: 357) gerektirir, bu kapasite kuşkusuz kapitalizmde vardır, dahası teknolojik gelişmişlik ve pozitif bilim günümüzde bu kapasiteyi eşsiz biçimde artırmıştır. Diğer taraftan bu düzeyde ele alma ve tahayyül etme kapasitesi söylemde hâkim konum edinmiştir. ${ }^{16}$ Fakat bunun karşısında sayısız prosedür ve süreçlerde bölünmüş ve parçalanmış bir mekân da söz konusudur. Bu parçalanmışlığı makro düzlemde, mekânın devletlere, idari bölgelere ayrılmasından, meso ve mikro düzeyde ise kentsel mekânın parsellenmesine kadar uzanır. Bu parçalanmışlığı da tıpk1 mekânı global ölçekte tahayyül eden "dünya düzdür" (Friedman, 2005) söylemi gibi belirli bir ideoloji içerir, belli bir ideolojiye hizmet edip işlem görür. Fakat "asıl katkısı perakende (hisselerle) satışa yöneliktir" (Lefebvre, 2014: 358). Ama yine de bu parçalanmışlığın her zaman daha yüksek düzlemdeki tahayyülü ve yerel ölçekteki pratik için bir engel oluşturacağı unutulmamalıdır. Bu ise birikim süreçleriyle ve meta mübadelesiyle doğrudan bağlantılıdır. Kapitalizmin soyut mekânının mekân temsili ile mekânsal pratiği arasındaki uyuşmazlıktan kaynaklanır. Şöyle ki meta zincirleri (mübadele ağları) dünya çapında örgütlenmiş ve düzenlenmiştir: ulaşım ağları, satış ve satın alma ağları. Böylece, "potansiyel olarak sonsuz sayıda metayı birbirine ekleyen meta dünyas1, mekân üzerine, hatta belli bir mekân kavramı üzerine önerme ve eylemlere yol açar" (Lefebvre, 2014: 345). Bu bağlamda akla gelen yine "dünya düzdür" önermesi veya "dünya düzdür" mekân temsilidir. Oysa kullanım (tüketim), mekân temsiliyle değil mekânsal pratiğiyle tanımlanır, yani kullanım her zaman yerel ve somuttur, onun "her zaman yerel bir özelliği vardır. Mübadele dünya mekânını işgal etse de (dolaşımlar ve ağlar) burada ya da orada tüketilir" (Lefebvre, 2014: 345). Bütünü temsil eden mübadele ağları, para dolaşımları, para transferleri ve buna tekabül eden belirli bir soyut mekân temsili ile parçayı temsil eden kullanım (tüketim) ve buna tekabül eden somut mekânsal pratik arasındaki makul karşıtlık, diyalektik çelişkiye dönüşür ve böylece mekân soyut-somut, homojen ama yine de parçalı bir nitelik kazanır (Lefebvre, 2014:

\footnotetext{
${ }^{16} \mathrm{Bu}$ açıdan neo-liberalizmin savunucularından özellikle Thomas Friedman'ın, neo-liberal söylemini tam olarak özetleyen "dünya düzdür" tabiri ve onun çok tartışılan aynı başlığı taşıyan kitabını belirtmek gerekir (Friedman, 2005).
} 
345-46). Bu diyalektik çelişki söz konusu olduğu için toplumsal mekân "hem bütün ve kırık, hem de genel ve parçalıdır" (Lefebvre, 2014: 358).

Soyut mekânın bütün-parça çelişkisi çerçevesinde, bunun sonucu olan merkez-periferi çelişkisi de söz konusudur. Hatta merkez ile periferi arasındaki çelişki bütün ile parça çelişkisinin içindeki hareketini belirler (Lefebvre, 2014: 358). Zihinsel olsun veya toplumsal olsun, merkezlik belirli bir mekân içinde olanları bir araya getirir ve onların buluşmasını sağlar, dolayısıyla sıkışıklık ve yoğunluk merkezliğin özellikleridir. Bir biçim olarak merkezlik anlık olanı genel olana bağlar, yerel olanı global olana bağlar. Merkezlik ve merkez ile periferi karşıtlığı her zaman var olmuştur, fakat kapitalizmin soyut mekânında merkezliğin farklı bir yönelimi vardır. Soyut mekânda merkezlik bütünsel olmak ister, 'yüksek bir siyasal-devletçi ya da 'kentsel' - rasyonelliği tanımlama iddiasinda bulunur" (Lefebvre, 2014: 336-37). Merkezlik belirli nesneleri kendine çekip bir araya getirir, dolayısıyla biçim edinir, ayrıca işlevsel bir gerçeklik de kazanır, şöyle ki merkezin etrafında belirli bir mekânın yapısı örgütlenir ve merkezin biçimi ve işlevi bir pratiğe katkıda bulunur (Lefebvre, 2014: 397). Fakat her şeyin yoğunlaşmasını ve içermesini sağlayan merkezlik aynı ölçüde dışlama ve dağıtma üzerinde de temellenir, dışlama ve dağıtma da onun işlev kapsamına girer, tıpkı yoğunlaştırma aracılığıyla biçimsel ve işlevsel gerçeklik edindiği gibi, dışlama aracılığıyla da merkezlik kendi varlığını bulur, periferi ve dışlanmış olan karşısında merkezlik olarak karşımıza çıkar. Dolayısıyla, merkezlik (merkez-periferi çelişkisi) hem yoğunlaştıran hem de dağıtan, hem kapsayan hem dişlayan işlevleri aracılığıyla bütün-parça çelişkisi içerisindeki hareketi belirler.

Yukarıda ele alınan çelişkilerin ileri kapitalizmin soyut mekânının en temel çelişkileri olduğu söylenebilir. Bu çelişkiler bağlamında bunlardan ayrı olmayan başka çelişkiler de söz konusudur (örneğin mülk edinme ile sahiplenme arasındaki çelişki). Fakat onların ele alınması, kendi özellikleri nedeniyle somut bağlamlarda incelenmesi daha uygun olabilir. Ayrıca, somut bir bağlamda çelişkili mekânın incelemesi yukarıdaki genel ve temel çelişkilere ilaveten, belirli bir toplumda ileri kapitalizmin işleyişine ve ona tekabül eden (üretilen) mekâna özgü çelişkiler dizisini de ortaya çıkartabilir.

\section{Mekânsal Üçlü}

Lefebvre'ye göre mekânın deneyimlenmesi üç temel unsurdan, algılanan, tasarlanan ve yaşanan unsurlardan oluşmaktadır ve bize bu unsurların mekânsal kavramsallaştırması olarak mekânsal pratik, mekân temsili ve temsili mekândan oluşan üçlüyü önerir. Üçlü, hem her üretim tarzında ve toplumda mekânın üretimini anlamlandırmasına ve mekânın deneyimlenmesinin incelenmesine hem de zihinsel, toplumsal ile fiziksel mekânların karşı1ıklı ilişkileri, karşıtlıkları ve düzenlenişlerini incelemeye imkân sağlamaktadır. Yukarıdaki mekân dönemsel- 
leştirmesi ve burada ele alınan mekânsal üçlü Lefebvre'nin mekân teorisinin temelidir.

Lefebvre, üçlü ve onun unsurları konusunda çalışmasının başlangıcında belirli bir tanımlamaya girişse de (Lefebvre, 2014: 67-75), bu unsurların kapsam ve içerik ile ilgili detayları, Lefebvre'nin somut tarihsel dönemlerin mekân analizinde ortaya çıkmaktadır. Tüm çalışmasında rastlanan üçlünün unsurlarının ele alınış1 "mekânik bir çerçeve veya topoloji değildir, üç momentin birbirine bulaştığı, akışkan ve canlı diyalektik bir yalınlaştırmadır" (Merrifield, 2013: 109). Fakat böyle bir tarzın kullanımı, aslında Lefebvre'nin sunduğu çerçevenin hem gücünü hem de zaafını oluşturmaktadır. Şöyle ki Lefebvre'nin argümanlarının tarzı, onları "kolaylıkla özetlemesine" imkân tanımamaktadır ve "tartışma ve merak uyandıracak biçimde tasarlanan projesinde kullandığı metaforlar ve örnekler basit parametreler dizisine indirgenemez", bu ise Lefebvre'nin taraftarlarına göre onun güçlü yönlerinden biri, eleştirmenler için ise sorunlu yönüdür (Unwin, 2000: 13). Bunlardan yola çıkarak, Lefebvre'nin, üçlünün unsurlarının tanımına burada kısaca yer verilecektir, zira bunları somut bağlamda ele alınması durumunda daha anlaşılabilir olur ve Lefebvre'nin yaklaşımına da daha uygun olur, çünkü kendisinin de belirttiği gibi,

Üçlü: algılanan - tasarlanan - yaşanan (mekânsal olarak: mekân pratiği - mekân temsili - temsil mekânları), soyut bir "model" statüsü atfedilirse kapsamını yitirir. Ya somutu ("dolaysız"1 değil) ele geçirir ya da kısıtlı - diğer ideolojik dolayımlardan biri olarak - bir önem taşır (Lefebvre, 2014: 69).

\section{Mekânsal Pratik (Algılanan Mekân)}

Lefebvre'ye göre bir toplumun mekânsal pratiği kendi mekânını yaratır. Bu mekânsal pratik ise mekânı deşifre ederek keşfedilir. İleri kapitalizmde mekânsal pratik gündelik gerçekliği ile kentsel gerçekliği sıkı sıkıya birleştirir (Lefebvre, 2014: 67). Mekânsal pratik, "üretimi ve yeniden üretimi nispi bir bağl1lık içinde sürekliliği sağlayan her toplumsal oluşuma has özgül yerleri ve mekânsal kümeleri” kapsar (Lefebvre, 2014: 63). Mekânsal pratik ilk olarak maddi bir gerçeklik olan mekân ile ilgilidir. Binalar, yapılar, çalışma yeri, özel alan ve boş vakit alanlarını birbiriyle bağlayan yol ve ağları kapsar, dolayısıyla “ampirik olarak gözlemlenir" (Lefebvre, 2014: 410). Lefebvre'nin somut örneğine başvurulursa modern zamanların mekânsal pratiği "banliyödeki bir toplu konutta oturan birinin gündelik hayatıyla tanımlanır" (Lefebvre, 2014: 68). Fakat mekânsal pratik aynı zamanda fiziksel yapılı çevrenin üretim ve yeniden üretim süreçlerini kapsar, dolayısıyla planlama ve ilgili disiplinlerin pratikleriyle ilgilidir ve bunun aracıllğıyla mekânsal pratik, tasarlanan mekân ile sıkı bir ilişki içine girer. Kendi nitelikleri dolayısıyla, yani fiziksel mekân ile ilgili olduğu için, bu, aynı zamanda algılanan mekândır, çünkü mekânsal pratikler mekânın doğrudan deneyimlenmesini sağlar. O yüzden Lefebvre mekânsal pra- 
tikleri aynı zamanda algılanan mekân olarak tanımlamaktadır. Bu nitelikleri nedeniyle mekânsal pratikler "mimari, (resmi söylemden alınan terimle) şehircilik, parkur ve yerlerin (toprağın) düzenlenmesi, gündelik hayat ve elbette kent gerçekliği gibi çeşitli düzeylerde saptanır, tarif edilir, analiz edilir" (Lefebvre, 2014: 410).

\section{Mekân Temsilleri (Tasarlanan Mekân)}

$\mathrm{Bu}$, planlamacıların, şehircilerin, teknokratların, kimi sanatçıların mekânıdır, bir toplumun (bir üretim tarzının) içindeki egemen mekândır. Mekân temsilleri varoluşuyla "parçalayan ve düzenleyen teknokratlar"a (Lefebvre, 2014: 68) borçlu olduğu için "bilgilere, işaretlere, kodlara, 'cephesel' ilişkilere bağl1"dır (Lefebvre, 2014: 63) ve "sözel, dolayısıyla entelektüel olarak oluşturulmuş bir göstergeler sistemine yönelme eğilimi gösterir" (Lefebvre, 2014: 68). Mekân temsilleri, etkin bilgi ve ideoloji aracılığıyla bu bilgi ve ideolojiyi mekânsal dokularında yansıtırlar, dolayısıyla "mekân üretiminde mekân temsillerinin önemli bir kapsamı ve özgül bir etkisi olur" (Lefebvre, 2014: 71). Bu kapsamı ve rolü nedeniyle mekân temsilleri, kurulu düzenin yani siyasi iktidarın, hâkim ideolojinin (veya söylemin) ve hâkim ekonomik düzenin mantığına göre düzenlenmiş, örgütlenmiş ve üretilmiş mekândır ve "ideoloji tarihinin parçasıdır" (Lefebvre, 2014: 139). Zihinsel olarak düşünülmüş, 'tasarlanmış', sonradan nesneleşmiş planlardan, simgelerden vs. oluşan bu mekân soyutlama içerir, şöyle ki bu mekân zihinsel olarak düşünülmüş ve belirli bir mekânsal pratik aracılığıyla nesneleşmiştir. Bu nedenle temsil mekân aynı zamanda tasarlanan mekân olarak da tanımlanır. Fiziksel dokuya etki kapsamı ve öneminden dolayı mekân temsilleri, mekânsal pratiklerinden ve onunla ilişkili olan mekân deneyimlenmesinden ayrılmaz. Onunla sıkı bir ilişki içerisindedir.

Genel bir somutlama yapılırsa, mekân temsilinin, mekânın bölgelere ayrılmas1, parsellenmesi, mekânın bir iş bölümüne ve uzmanlaşmaya dâhil edilip, işlevlerin, insanların ve şeylerin mekândaki ayrım veya birleşimini sağlayan uygulama ve pratiklerin dayanağı olduğu söylenebilir.

\section{Temsil Mekânları (Yaşanan Mekân)}

Temsil mekânlarının, üçlünün diğer iki unsuruna kıyasla daha zor saptanabilecek bir unsur olduğu söylenebilir. Bunun temel nedeni, temsil mekânının, imgelem ile ilişkili olması, "toplumsal yaşamın yasadışı ve yeraltı tarafına bağlı" olması, "karmaş1k sembolizmler"den (Lefebvre, 2014: 63) oluşmasıdır. Bir diğer önemli neden, temsil mekânlarının öznel olmasıdır, şöyle ki "kullanıcıların her günkü edimlerin"in (Lefebvre, 2014: 364) somut mekânıdır, hesapların değil "öznelerin" mekânıdır, "bir halkın ve bu halka mensup her bir kişinin tarihi”" (Lefebvre, 2014: 70) ile ilgilidir, dolayısıyla hesaplar içeren tasarlanmış mekân ve mekânsal pratiklere kıyasla "ne tutarlığa ne de bağlantıya mecburdur" 
(Lefebvre, 2014: 70). Bu kullanıcıların ve oturanların mekânıdır, şöyle ki bu mekân

yaşanır, konuşur; duyumsal bir çekirdeği ya da merkezi vardır: Ego, yatak, oda, konut ya da ev; meydan, kilise, mezarlık... Bu mekânlar, tutku ve eylem yerlerini, yaşanan durumların yerlerini kapsar, dolayısıyla zamanı doğrudan içerir (Lefebvre, 2014: 71).

Tasarlanmış mekân karşımıza teknokratların mekânı olarak çıkar, dolayısıyla sadece hesaplar içermez aynı zamanda kendine özgü bir teknik dil (jargon) içerir, oysa temsil mekânı yaşananların ve kullananların sembollerini, imgelerini ve argo dilini içerir, o yüzden "niteleyicidir, akışkandır, dinamikleşmiştir- çeşitli nitelemeler edinebilir" (Lefebvre, 2014: 71).

Aktarıldığı üzere, mekânın üretimi içerisinde mekân temsilinin rolü ve kapsamı çok önemlidir, oysa ona kıyasla temsil mekânlarının ürünü genellikle sadece sembolik eserlerdir, yani mekânın üretimi açısından temsil mekânı pek üretici değildir. $\mathrm{Bu}$ eserler, hatta bazen "estetik" bir akım veya eğilime yol açarlar, fakat bu belli bir süre sonra yok olur (Lefebvre, 2014: 71) veya açıkça gözlenebilen durumdan yine toplumsal mekânın yasadışı ve 'yeraltı' kısmına saklanırlar. Mekânsal bir tezahürü de bulan ve aslında belirli bir toplumsal mekân üretimi anlamına da gelen, gündelik hayatta neredeyse hiç gözlemlenemeyen LGBT yürüyüşleri, karnavallar, şenlikler temsil mekânlarının en basit örnekleridir.

Gündelik hayat, temsil mekânları içinde şekil bulur (Lefebvre, 2014: 139), fakat gündelik hayatın sıradanlığı, belirli kurallara göre düzenlenişi ve standartlığ 1 , toplum üyeleri tarafindan bu mekânın kavranmasını zorlaştırır. Kavrama söz konusu olunca ise standartlı̆̆ içine sığmadığı için tepkiye neden olur veya farklı bir gündelik hayatın mümkün olacağına işaret eder. Dolayısıyla, temsil mekânları aynı zamanda özgürleştirici bir potansiyel de taşırlar; egemen söylemi ve pratiği alt üst edebilirler. Bu potansiyel ve az çok bağdaşık sistemlerine yönelim için temsil mekânı aynı zamanda egemen söylem tarafından marjinalleştirilmeye çalışı1ır, dolayısıyla "hegemonyacı söylemlerin kenarlarında, kurumların boşluklarında ve iktidar-bilgi aygıtının açık ve çatlaklarında" (Soja, 1999: 272-73) yer alırlar. 
Şekil 2. Beden, Mekân ve Mekân Deneyimlenmesi ${ }^{17}$

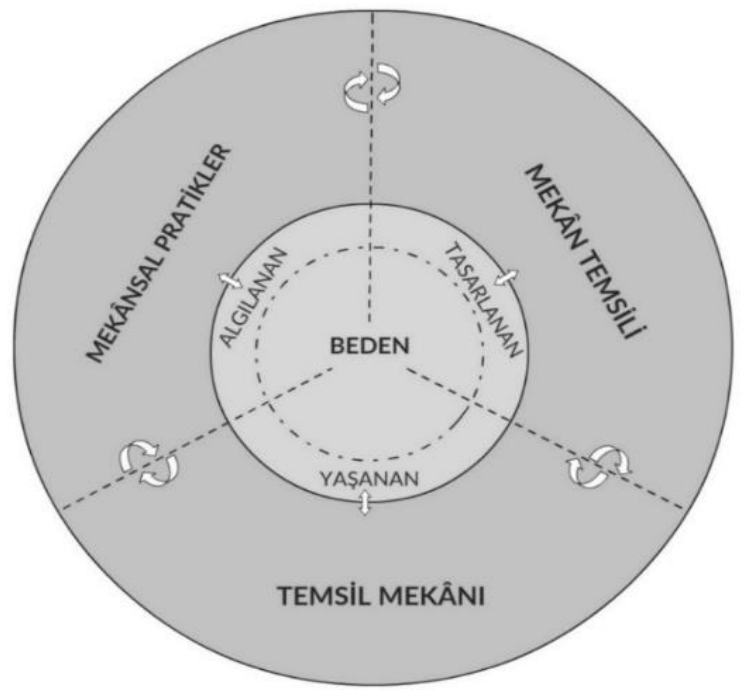

Toplumsal mekânı anlamlandırmaya yönelik bu üç mekân birbirinden hiçbir zaman ayrı görülmemeli, çünkü artık yukarıda da görüldügü üzere bunlar süregelen bir etkileşim, karşıtlık ve çelişki içerisindedirler. Ancak analitik kolaylık sağlamak ve kavramsal bir çerçeve belirlemek için bunlar ayrı ayrı tanımlanır, dolayısıyla nihai analiz bunları hep beraber analiz etmelidir, onların etkileşimi, karşı1tlk ve diyalektik çelişkileri incelenmelidir. Bunlar arasında her zaman bir ayrım yapıldığında "böyle bir ayrım fazlasıyla ihtiyatla kullanılmalıdır. Üretici birliği tesis etmesi gerekirken, tam tersine hemen ayrışmalara yol açar." (Lefebvre, 2014: 71). Bu bağlamda bir diğer önemli husus, belirtildiği üzere Lefebvre'nin analizinin Avrosentrik olmasıdır. Lefebvre'nin kendisi de bunun farkındadır ve örneğin Doğu'da (örneğin Çin'de) temsil mekânı ile mekân temsilleri arasındaki farklılığın tanınmış olup olmadığı sorusundan bahseder (Lefebvre, 2014: 71-72). Dolayısıyla hem mekânın bir bütünlük olarak kavranışının sağlanması için üçlünün unsurlarının birbirinden ayrılmasına ihtiyatla yaklaşılmalıdır hem de "bu ayrımın genelleşebileceği baştan kesin olmadı̆̆ı" (Lefebvre, 2014: 71) için somut bir bağlamda bu unsurların ne kadar birbirinden ayırabileceği sorusuna cevap aranmalıdır.

Kendi özellik ve niteliklerine göre, farklı üretim tarzı ve toplumlara göre mekânsal pratikler, mekân temsilleri ve temsili mekânlar, mekânın üretimine farklı ölçüde müdahale ederler, ayrıca bunlar arasındaki ilişkiler hiçbir zaman basit ve istikrarlı değildir (Lefebvre, 2014: 74). Mekân ve onun üretimi nasıl

\footnotetext{
${ }^{17} \mathrm{Bu}$ şema Lefebvre'nin kuramına dayanarak yazar tarafından hazırlanmıştır.
} 
çok taraflı ve çok boyutlu bir süreç ise bu unsurlar arasındaki ilişkiler de böyle bir süreç temsil ederler (bkz. Şekil 2). Bu süreçte, üç moment arasında sürekli hareket, örtüşme, yer değiştirme, 'sürtüşme' ortaya çıkabilir, temsil mekânı mekân temsili tarafından işgal edilir, yerini ona bırakır ya da farklı süreçler nedeniyle temsil mekânı yasadışı tarafından çıkıp toplumsal mekânda kendi yerini kazanır. Bu süreçlerde özellikle ‘beden' hep dikkate alınmalıdır, çünkü Lefebvre, üçlüyü, mekânı ve mekânın üretimi süreçlerini insan ve onun bedeni tarafından deneyimlenmesinin incelenmesi için sunar. Başka bir deyişle, beden bu üçlüde 'merkezi' bir konuma sahiptir ve temel eksendir.

Mekânsal pratikler "üretimi ve yeniden üretimi, nispi bir bağl1lık içinde süreklilik sağlayan her toplumsal oluşuma has özgül yerleri ve mekânsal kümeleri kapsa[dığı]" (Lefebvre, 2014: 63) için üretim ve yeniden üretimin iç içe girmiş olan üç düzeyle (biyolojik yeniden üretim düzeyi, iş gücünün yeniden üretimi düzeyi, toplumsal üretim ilişkilerin yeniden-üretimi) sıkı bir bağ içerisindedir ve bu bağ aracılığıyla temsil mekânı ve mekân temsili ile bir araya gelir, genel olarak toplumun ve onun her üyesinin, toplumsal mekânla ilişkilerinde yeterlik ve performans sağlar. ${ }^{18}$

\section{Sonuç}

Makalede Lefebvre'nin 'Mekânın Üretimi' kitabında öne sürülen mekân kuramının okumasıyla bu kuramın temel yapısını oluşturan iki unsur -mekân dönemselleşitmesi ve mekânsal üçlü- ele alınmıştır. Lefebvre'nin "(toplumsal) mekân (toplumsal) bir üründür" varsayımının bir içerimi olarak öne sürdüğü mekân dönemselleştirmesini ele alarak her üretim tarzında üretilmekte olan mekânlar -mutlak, kutsal, tarihsel, soyut ile çelişkili mekân- değerlendirilmiştir ve böylece Lefebvre tarafindan öne sürülen 'mekân tarihi' değerlendirilmiştir. Son olarak toplumsal mekânın araştırılması ve mekânın üretiminin ortaya çıkartılması için Lefebvre'nin önerdiği mekânsal üçlü ele alınmıştır. Makalede bu hususlar ele alınırken genel olarak Lefebvre'ye başvurulmakla beraber aynı zamanda onun kuramının kuramsal ve kavramsal çerçevesinin okumasına ve anlaşılmasına imkân sağlayacak başka kaynaklardan da yararlanılmıştır. Böylece herhangi bir mekân ve zaman bağlamında toplumsal mekânın araştırılması ve mekânın üretimi süreçlerinin ele alınması için yapısal ve kavramsal bir çerçeve çizilmiştir. Dolayısıyla, makalede çizilen yapısal ve kavramsal çerçeve daha

\footnotetext{
${ }^{18}$ Lefebvre, kendisi de belirttiği üzere yeterlik ve performans kavramları Chomsky'nin Üretici Dilbilgisi kuramından ödünç almıştır. Fakat çalışmasında bu kavramların üzerinde fazla durmadığı ve tanımlamadığı için belirtelim ki Chomsky'nin kuramında yeterlik, bireyin cümleler kurma ve onları anlamaya yönelik temel bilinçaltı yeteneğidir. Bu bir bireyin belirli dilbilgisi kurallarıyla tanıklı̆ı̆dır, yani "konuşan-dinleyenin kendi dilinin bilgisidir" (Chomsky, 1965: 4). Yeterlik, bireye sayısız cümleler kurma ve anlamasına imkân sağlar, dahası gramer kurallarına uygun olmayan cümleleri anlamaya da imkân sağlar. Oysa performans "somut durumlarda dilin fiili kullanımıdır" (Chomsky, 1965: 4) yani belirli bir dilin pratik kullanımını içerir, bu ise yeterliğe her zaman uymayabilir.
} 
somut bir bağlamda uygulandığı takdirde Lefebvre'nin kuramının epistemolojik boyutlarının incelenmesine imkân sağlayabilir ve kuramsal düzlemde mekân tartı̧̧malarına katkı sağlayabilir. Ayırca çizilen çerçeve somut bağlamlarda mekân araştırmaları için kullanışlı ve tutarlı bir çerçeve olarak uygulanabilir.

\section{Kaynakça}

Boer, R. (2015), Marxist Criticism of the Hebrew Bible, Bloomsbury Publishing, 2. Bask1, London.

Brenner, N. (1997a), “Global, Fragmented, Hierarchical: Henri Lefebvre's Geographies of Globalization", Public Culture, Cilt 10, Sayı 1, s. 135-167.

Brenner, N. (1997b), "State Territorial Restructuring and the Production of Spatial Scale: Urban and Regional Planning in the Federal Republic of Germany, 19601990", Political Geography, Cilt 16, Say1 4, s. 273-306.

Brenner, N. (1999), "Globalisation as Reterritorialisation: The Re-scaling of Urban Governance in the European Union”, Urban Studies, Cilt 36, Sayı 3, s. 431-451.

Brenner, N. (2000), "The Urban Question as a Scale Question: Reflections on Henri Lefebvre, Urban Theory and the Politics of Scale", International Journal of Urban and Regional Research, Cilt 23, Say1 2, s. 371-378.

Brenner, N. (2001), "The Limits To Scale? Methodological Reflections on Scalar Structuration", Progress in Human Geography, Cilt 25, Say1 4, s. 591-614.

Brenner, N. (2002), "Decoding the Newest "Metropolitan Regionalism" in the USA: A Critical Overview”, Cities, Cilt 19, Sayı 1, s. 3-21.

Brenner, N. (2003), "Metropolitan Institutional Reform and the Rescaling of State Space in Contemporary Western Europe", European Urban and Regional Studies, Cilt 10, Sayı 4, s. 297-324.

Brenner, N. (2004a), New State Spaces: Urban Governance and the Rescaling of Statehood, Oxford University Press, Oxford.

Brenner, N. (2004b), "Urban Governance and the Production of New State Spaces in Western Europe, 1960-2000”, Review of International Political Economy, Cilt 11, Sayı 3, s. 447-488.

Brenner, N. ve Elden, S. (2009), "Henri Lefebvre on State, Space, Territory", International Political Sociology, Cilt 3, Say1 4, s. 353-377.

Brenner, N. ve Schmid, C. (2015), “Towards a New Epistemology of the Urban?”, City, Cilt 19, Sayı 2-3, s. 151-182.

Cassirer, E. (1944), An Essay on Man: An Introduction to a Philosophy of Human Culture, Yale University Press, New Haven.

Chomsky, N. (1965), Aspects of the Theory of Syntax. Aspects of the Theory of Syntax, MIT Press, Cambridge, Mass.

Dobb, M. (1946), Studies in the Development of Capitalism, International Publishers, New York. 
Dobb, M., Sweezy, P., Lefebvre, G., Procacci, G., Merrington, J., Hill, C. ve Takahashi, K. (1985), The Transition from Feudalism to Capitalism, Verso, London.

Friedman, T. L. (2005), The World is Flat : A Brief History of the Twenty-First Century, Farrar, Straus and Giroux, New York.

Gottdiener, M. (1982), “Disneyland: A Utopian Urban Space”, Urban Life, Cilt 11, Say1 2, s. 139-162.

Gottdiener, M. (1987), "Space as a Force of Production: Contribution to the Debate on Realism, Capitalism and Space", International Journal of Urban and Regional Research, Cilt 11, Sayı 3, s. 405-416.

Gottdiener, M. (1994), The Social Production of Urban Space, University of Texas Press, 2. Bask1, Austin.

Gottdiener, M. (2001a), The Theming of America: American Derams, Media Fantasies, and Themed Environments, Westview Press, 2. Bask1, Boulder.

Gottdiener, M. (2001b), "The Consumption of Spaces and the Spaces of Consumption”, Gottdiener, M. (Ed.), New Forms of Consumption: Consumer, Culture and Commodification, Rowman and Littlefield, Lanham, MD, s. 265-286.

Gottdiener, M. (2011), "Socio-Semiotics and the New Mega Spaces of Tourism: Some Comments on Las Vegas and Dubai", Semiotica, Cilt 183, Sayı 1/4, s. 121-128.

Grönlund, B. (1993), Lefebvre's Ontological Transformation(s) of Space, Nordplan, Stockholm.

Harvey, D. (2006), “Space as a Keyword”, Gregory D. ve Castree N. (Ed.), David Harvey: A Critical Reader, Blackwell, Oxford, s. 270-293

Lefebvre, H. (1976a), Survival of Capitalism: Reproduction of the Relations of Production, (Çev. B. Frank), St. Martin's Press, New York.

Lefebvre, H. (1976b), Everyday Life in the Modern World, (Çev. R. Sacha), Harper Torchbook, New York.

Lefebvre, H. (1991), Critique of Everyday Life, Volume 1: Introduction, (Çev. M. John), Verso, London.

Lefebvre, H. (1996), Writings on Cities, (Çev. E. Kofman ve E. Lebas), Blackwell Publishers, Oxford.

Lefebvre, H. (2002), Critique of Everyday Life, Volume 2: Foundations for a Sociology of the Everyday, (Çev. M. John), Verso, London.

Lefebvre, H. (2003), The Urban Revolution, (Çev. R. Bononno), The University of Minnesota Press, Minneapolis.

Lefebvre, H. (2009), Dialectical Materialism, (Çev. S. John,), The University of Minnesota Press, Minneapolis.

Lefebvre, H. (2014), Mekânın Üretimi, (Çev. I. Ergüden), Sel Yayıncılık, 2. Bask1, İstanbul.

Merrifield, A. (2013), Henri Lefebvre: A Critical Introduction, Routledge, London. 
Mumford, L. (2013), Tarih Boyunca Kent: Kökenleri Geçirdiği Dönüşümler ve Geleceği, (Çev. G. Koca ve T. Tosun), Ayrıntı Yayınları, 2. Baskı, İstanbul.

Pirenne, H. (1946), Medieval Cities: Their Origins and the Revival of Trade, (Çev. F. D. Halsey), Princeton University Press, 4. Bask1, Princeton.

Shields, R. (2005), Lefebvre, Love, and Struggle: Spatial Dialectics, Routledge, London.

Smith, N. (2008), Uneven Development: Nature, Capital, and the Production of Space, The University of Georgia Press, 3. Bask1, Athens.

Soja, E. (1989), Postmodern Geographies: The Reassertion of Space in Critical Social Theory, Verso, London.

Soja, E. (1996), Thirdspace: Journeys to Los Angeles and Other Real-and-Imagined Places, Basil Blackwell, Oxford.

Soja, E. (1999), Thirdspace: Expanding the Scope of the Geographical Imagination, Massey D., Allen J. ve Sarre P. (Ed.), Human Geography Today, Polity Press, Cambridge, s. 260-278.

Soja, E. (2000), Postmetropolis: Critical Studies of Cities and Regions, WileyBlackwell, Oxford.

Soja, E. (2014), My Los Angeles: From Urban Restructuring to Regional Urbanization, University of California Press, Berkeley.

Unwin, T. (2000), “A Waste of Space? Towards a Critique of the Social Production of Space....", Transactions of the Institute of British Geographers, Cilt 25, Say1 1, s. 11-29. 